\title{
New Evidence on the Urbanization of Global Poverty
}

\author{
Martin Ravallion, Shaohua Chen and Prem Sangraula* \\ Development Research Group, World Bank
}

We find that one-quarter of the world's consumption poor live in urban areas and that the proportion has been rising over time. By fostering economic growth, urbanization helped reduce absolute poverty in the aggregate but did little for urban poverty. Over 1993-2002, the count o the "\$1 a day" poor fell by 150 million in rural areas but rose by 50 million in urban areas. The poor have been urbanizing even more rapidly than the population as a whole. There are marked regional differences: Latin America has the most urbanized poverty problem, East Asia has the least; there has been a "ruralization" of poverty in Eastern Europe and Central Asia; in marked contrast to other regions, Africa's urbanization process has not been associated with falling overall poverty. Looking forward, the recent pace of urbanization and current forecasts for urban population growth imply that a majority of the world's poor will still live in rural areas for many decades to come.

Key words: Urban poverty, rural poverty, migration, urban population growth.

JEL: I32, O15, O18

World Bank Policy Research Working Paper 4199, April 2007

The Policy Research Working Paper Series disseminates the findings of work in progress to encourage the exchange of ideas about development issues. An objective of the series is to get the findings out quickly, even if the presentations are less than fully polished. The papers carry the names of the authors and should be cited accordingly. The findings, interpretations, and conclusions expressed in this paper are entirely those of the authors. They do not necessarily represent the view of the World Bank, its Executive Directors, or the countries they represent. Policy Research Working Papers are available online at http://econ.worldbank.org.

\footnotetext{
We are grateful to the many colleagues in the Bank and staff of governmental statistics offices throughout the world who have helped us in assembling the data set used here, and answering our many questions. Helpful comments were received from Stephan Klasen, Dominique van de Walle, seminar participants at the World Bank, the University of California, Berkeley, and the International Food Policy Research Institute. This paper was supported in part by the Bank's 2008 World Development Report. These are the views of the authors, and should not be attributed to the World Bank or any affiliated organization.
} 


\section{Introduction}

The urbanization of the developing world's population has been viewed in different ways by different observers. To some it has been seen as a positive force in economic development, as economic activity shifts out of agriculture to more remunerative activities. Indeed, longstanding theories of economic development, going back to Arthur Lewis and Simon Kuznets, have viewed population urbanization as a core part of the process leading to economic growth and distributional change (including poverty reduction) in poor countries. By this view, new economic opportunities in urban areas attract rural workers, who gain directly, and there may also be positive feedback effects in rural areas. To others, urbanization has been viewed in a somewhat less positive light - a largely unwelcome forbearer of new poverty problems. Advocates of this view often point to (claimed) negative externalities of geographically concentrated poverty and irreversibilities due to various costs of migration, which can mean that migrants to urban areas cannot easily return to their old standard of living in rural areas.

Empirical knowledge for informing this debate has been rather limited and problematic. We do not even have a firm grip of the basic stylized facts, including the extent to which absolute poverty in the world is urban versus rural. While the premise of much development policy making is that extreme poverty in the developing world is primarily rural, there is a perception in some quarters that this has changed appreciably in recent rimes; indeed, some observers believe that poverty is now mainly an urban problem. In an early expression of this view, the distinguished scientific journalist and publisher Gerard Piel told an international conference in 1996 that "The world's poor once huddled largely in rural areas. In the modern world they have gravitated to the cities." (Piel, 1997, p.58).

This paper aims to throw new light on the extent to which poverty is in fact urbanizing in the developing world and what role, if any, population urbanization has played in poverty reduction. We report our results in studying a new data set created for this paper, covering about 90 developing countries with observations over time for about $80 \%$ of them. 
The motivation for this study, and the steps in our analysis, can be grouped around five claims. Let us begin with two widely-heard claims:

Claim 1: The majority of the developing world's population lives in rural areas, but the urban population share is rising and will soon exceed the rural share.

Claim 2: The incidence of absolute poverty is higher in rural areas of developing countries.

Support for Claim 1 has mainly come from the useful compilations of demographic data and population forecasts done by the UN Secretariat's Population Division, in its regular report, World Urbanization Prospects (WUP). The "urban" versus "rural" split of the population is largely based on national statistical sources. In the latter, an "urban area" is typically (though not universally) defined by a non-agricultural production base and a minimum population size. However, there are many differences between countries in the definitions used in practice; for example, the minimum population size can vary from two to five thousand. Some of the measured growth in the urban population stems from changes in the definition of an "urban area;" Goldstein (1990) describes how this happened in China during the 1980s. The distinction between "urban" and "rural" areas is also becoming blurred; urban areas are heterogeneous, with a gradation from "mega-cities" to towns. While very few people (ourselves included) question the validity of Claim 1 , there is in fact a cloud of doubt about definitions and magnitudes. ${ }^{1}$

The foundations for Claim 2 are no more secure. Almost all of our prevailing knowledge concerning the urban-rural poverty profile has come from country-specific poverty studies, using local poverty lines and measures. The World Bank's country-specific Poverty Assessments are examples of this type of evidence; compilations of the national (urban and rural) poverty measures can be found in the Bank's World Development Indicators (WDI; this is an annual publication; the latest issue is World Bank, 2006). Drawing on evidence from this type of data, Ravallion (2002) estimates that $68 \%$ of the developing world's poor live in rural areas.

1 The Panel on Urban Population Dynamics (2003) makes recommendations on how to address the problem of differening definitions of "urban", but the implementation of their recommendations is not feasible with the survey data used for poverty measurement currently available in most countries. 
Just as there are comparability problems in the population data, so too for the compilations of national poverty statistics. On top of the aforementioned inconsistencies in how "urban areas" are defined, there is the problem that different countries naturally have different definitions of what "poverty" means; for example, higher real poverty lines tend to prevail in richer countries, which tend also to be more urbanized. And the urban composition of the poor probably varies with the level of economic development and urbanization. The picture one gets may well be affected by such comparability problems, although (as we will explain later) there are theoretical ambiguities about the direction of bias in estimates of the urbanization of poverty.

We address some of the weaknesses in existing knowledge relevant to Claim 2, but we have no choice but to take as given the empirical foundations of Claim 1 - based on existing national-level definitions of "urban" and "rural." By estimating everything from the primary data (either directly from the unit-record data when available or from specially-designed tabulations from those data) we are able to assure a relatively high degree of internal consistency in quantifying the urban-rural poverty profile. We introduce a change in the methodology of the World Bank's global poverty counts using international poverty lines, which have not previously been split by urban and rural areas. ${ }^{2}$ We combine country-specific estimates of the differential in urban-rural poverty lines with existing Purchasing Power Parity exchange rates and survey-based distributions. ${ }^{3}$ Thus we make the first decomposition of the international "\$1 a day" poverty counts by urban and rural areas. We re-affirm Claim 2 from these new data. However, we also point to a number of continuing concerns about the available data.

What does Claim 1 imply for the future validity of Claim 2? Does population urbanization mean that the urban poverty problem will soon overtake the rural problem? We use our new estimates to assess the validity of three further claims:

2 The only previous estimate of the urban-rural split of poverty that we know of by Ravallion (2002) was essentially based on the poverty measures from the WDI, using country-specific poverty lines rather than an international line, such as the $\$ 1$ a day standard.

3 PPP exchange rates correct for the fact that non-traded goods tend to be cheaper in poorer countries (where wages are lower). We use the World Bank's PPPs. 
Claim 3: The urban sector's share of the poor is rising over time.

Claim 4: The poor are urbanizing faster than the population as a whole.

Claim 5: Population urbanization is a positive factor in overall poverty reduction.

Past support for Claims 3 and 4 has largely come from cross-country comparisons (from similar data sources to those supporting Claim 2), which suggest that the urban share of the poor tends to be higher in more urbanized countries and that the urban poverty rate tends to be higher relative to the overall rate, consistent with Claim 4 (Ravallion, 2002). Here too there are concerns about the empirical foundations of existing knowledge. There is no obvious reason why the comparability problems noted above with reference to Claims 1 and 2 would be time invariant, so biases in the measured pace of the urbanization of poverty cannot be ruled out. And the fact that the existing evidence for Claims 3 and 4, which are about dynamics, has largely come from cross-sectional data leaves room for doubt; possibly the pace of poverty's urbanization over time at country level will look very different to the cross-country differences observed at one date.

What will happen to aggregate poverty with urbanization? If nothing happens to the distribution of income within either urban or rural areas then Claim 2 implies that the overall poverty rate (urban + rural) will fall as the urban population share rises, consistent with Claim $5 .{ }^{4}$ This can be termed a "Kuznets process" of urbanization, whereby a representative slice of the rural distribution is transformed into a representative slice of the urban distribution. ${ }^{5}$ Given that the urban distribution has lower poverty, aggregate poverty must fall. If the urban sector also has higher inequality than the rural sector (as is typically the case in developing countries) then aggregate inequality will rise in the early stages of urbanization, but eventually fall. This is the famous Kuznets Hypothesis, first formulated by Kuznets (1955). The reality may well be more complex, with distributional changes within each sector and interlinkages; for example, even if urbanization puts upward pressure on urban poverty, there can be offsetting gains to the rural

\footnotetext{
$4 \quad$ This will hold for a broad class of population-weighted decomposable poverty measures; Atkinson (1987) reviews this class of measures.

5 For a thorough analysis of the distributional implications of urbanization under the Kuznets process see Anand and Kanbur (1993).
} 
economy, such as through rural labor-market tightening and remittances back to rural residents stemming from migration to urban areas.

Claim 4 is interpretable as the outcome of what can be termed a "mixed Kuznets process." Intuitively, urbanization entails gains to the poor (both directly as migrants and indirectly via remittances), but the gains are not large enough for all previously poor new urban residents to escape poverty. Thus the migration process puts a brake on the decline in urban poverty incidence, even when rural poverty and total poverty are falling. To give a sharp characterization of this effect, suppose that a proportion $\delta$ of the population shifts from rural to urban areas, of which a proportion $\alpha$ attains the pre-existing urban distribution of income (the successful migrants) while $1-\alpha$ keeps the rural distribution. (Only when $\alpha=1$ do we have the pure Kuznets process.) The initial difference in poverty rates between rural and urban areas is $H^{r}-H^{u}>0$ where $H^{k}$ is the headcount index in sector $k=u, r .{ }^{6}$ It is plain that this urbanization process will reduce aggregate poverty — the national headcount index falls by $\alpha \delta\left(H^{r}-H^{u}\right)$ - but it will increase the poverty rate in urban areas, which rises by $(1-\alpha) \delta\left(H^{r}-H^{u}\right) /\left(S^{u}+\delta\right)$, where $S^{u}$ is the initial urban population share.

The following section describes our methods and data. Section 3 assesses whether our estimates of urban and rural poverty measures for the developing world are consistent with Claims 2-4 while section 4 does the same for Claim 5. Section 5 looks at implications for the future urbanization of poverty and section 6 concludes.

\section{Measuring urban and rural poverty in the developing world}

We focus on poverty defined in terms of household consumption per capita. Following standard practices, the measures of household consumption (or income, when consumption is unavailable) in the survey data we use are reasonably comprehensive, including both cash spending and imputed values for consumption from own production. But we acknowledge that

\footnotetext{
6 The headcount index is the proportion of the population living in households with consumption per person below the poverty line.
} 
even the best consumption data need not adequately reflect certain "non-market" dimensions of welfare that differ between urban and rural areas, such as access to public services (invariably better in urban areas) and exposure to crime (typically more of a problem in urban areas).

We make two key assumptions about poverty measurement. Firstly, we confine attention to standard additively separable poverty measures for which the aggregate measure is the (population-weighted) sum of individual measures. This includes the two measures reported in this paper, the headcount index and the poverty gap index. ${ }^{7}$

Secondly, we also take it as axiomatic that simply moving individuals between urban and rural areas (or countries), with no absolute loss in their real consumption, cannot increase the aggregate measure of poverty. Relocation on its own cannot change aggregate poverty.

These assumptions justify confining our attention to absolute poverty measures, by which we mean the poverty line is intended to have a constant real value both between countries and between urban and rural areas within countries. ${ }^{8}$ A key issue is then how to deal with the fact that the cost-of-living (COL) is generally higher in urban areas. Casual observations suggest that relatively weak internal market integration and the existence of geographically non-traded goods can yield substantial cost-of-living differences between urban and rural areas. Any assessment of the urbanization of poverty that ignored these COL differences would simply not be credible. Yet existing Purchasing Power Parity (PPP) exchange rates used to convert the international line into local currencies do not distinguish rural from urban areas.

To address this problem we turn to the World Bank's country-specific Poverty Assessments (PA's), which have now been done for most developing countries. These are core reports within the Bank's program of analytic work at country level; each report describes the

\footnotetext{
$7 \quad$ The poverty gap index is the mean distance below the poverty line as a proportion of the line (where the mean is taken over the whole population, counting the non-poor as having zero poverty gaps.) On the larger set of additively separable measures see Atkinson (1987).

$8 \quad$ This does not allow the possibility that a new migrant to urban areas experiences relative deprivation. One can question how relevant this is for very poor people (Ravallion and Loskshin, 2005).
} 
extent of poverty and its causes in that country. ${ }^{9}$ The PA's are clearly the best available source of information on urban-rural differentials for setting international poverty lines, although they have not previously been used for this purpose.

The essential idea of this paper is to use country-specific urban and rural poverty lines from the PA's in setting the urban-rural differential in the international poverty lines. The fact that PA's have now been completed for most developing countries makes this feasible. Besides the change in methodology, our methods closely follow those outlined in Chen and Ravallion (2004), which provides the latest available update of the World Bank's global poverty measures for $\$ 1$ and $\$ 2$ a day. We follow the long-standing tradition in poverty measurement at the World Bank and elsewhere of relying on primary survey data to the maximum extent feasible.

An alternative approach to global poverty measurement is to combine pre-existing inequality measures at country level from survey data with the estimates of mean consumption or income from the national accounts (NAS). ${ }^{10}$ This is not a defensible option for doing an urbanrural split of global poverty measures, allowing for COL differences, since neither the inequality measures nor the NAS means would then be valid. This method is also questionable in the limiting case when the COL difference is zero. On the one hand, it is not clear that the NAS data can provide a more accurate measure of mean household welfare than the survey data that were collected precisely for that purpose. On the other hand, even acknowledging the problems of income underreporting and selective survey compliance, there can be no presumption that the discrepancies between survey means and the NAS aggregates (such as private consumption per

9 To given an indication of the scale of a PA, the average cost is about $\$ 250,000$. Most, but not all, PA's are public documents.

10 Examples are Bourguignon and Morrisson (2002), Bhalla (2002), Sala-i-Martin (2006) and Ackland, Dowrick and Freyens (2006). Note that the internal consistency of the compilations of existing inequality measures is also questionable; the measures differ in terms of the recipient unit (household versus individual) and the ranking variable (household versus per capita). Only by re-estimating consistently from the micro data (as we have done) is it possible to address these consistency problems. 
person) are distribution neutral; more plausibly the main reasons why surveys underestimate consumption or income would also lead to an underestimation of inequality. ${ }^{11}$

In almost all cases, the PA poverty lines were constructed using some version of the Cost-of-Basic-Needs method. ${ }^{12}$ This aims to approximate a COL index that reflects the differences in prices faced between urban and rural areas, weighted by the consumption patterns of people living in a neighborhood of the country-specific poverty line. This is consistent with the use of an absolute poverty standard across countries.

While our method appears to be the best option that is currently feasible, internal consistency is questionable if the urban-rural COL differential varies by income. This may stem from differences in the prices faced between the poor and others, or differences in consumption patterns. Then the differential from the PA may not be right for the international poverty lines. If the COL differential tends to rise with income then we will tend to overestimate urban poverty by the $\$ 1$ a day line in middle-income countries relative to low-income countries, given that the PA poverty line will tend to be above the international line for most middle-income countries. To help assess robustness, we also estimate poverty measures for a " $\$ 2$ a day" line that is more typical of the poverty lines used in middle-income countries.

A data constraint that can also create internal inconsistencies is that in setting poverty lines, location-specific prices are typically only available for food goods. Also, while nutritional requirements for good health provide a defensible anchor in setting a reference food bundle, it is less obvious in practice what normative criteria should be applied in defining "non-food basic needs." The problem is compounded by the fact that poor rural infrastructure (such as

\footnotetext{
11 For example, Banerjee and Piketty (2005) attribute up to 40 percent of the difference between the (higher) growth of GDP per capita and (lower) growth of mean household per capita consumption from household surveys in India to unreported increase in the incomes of the rich. Selective compliance with random samples could well be an equally important source of bias, although the sign is theoretically ambiguous; Korinek et al. (2006) provide evidence on the impact of selective non-response for the US. On the problems of selective non-response in surveys more generally see Groves and Couper (1998). 12 The precise method used varies from country-to-country, depending on the data available. On the methods sued in setting poverty lines see Ravallion $(1994,1998)$.
} 
incomplete electrification) means that some non-food goods found in urban areas will not be consumed in rural areas.

In addressing these concerns in applied poverty measurement (including the Bank's PAs), the non-food component of the poverty line is typically set according to food demand behavior in each sub-group of the population for which a poverty line is to be determined. Different methods are found in practice, but they share the common feature that the non-food component of the poverty line is found by looking at the non-food spending of people in a neighborhood of the food poverty line, which is the cost for that sub-group of a reference food bundle (which may itself vary according to differences in relative prices or other factors). Thus spending on nonfood items such as clothing and housing is included consistently with the food poverty line. This typically entails a larger (sometimes appreciably larger) allowance for non-food spending in urban areas.

While this approach appears to be a reasonable and operational approach to the problem of setting a non-food poverty line, it may well introduce some degree of relativism into the poverty measures, depending on the properties of the food Engel curves, which may shift with factors that are not deemed relevant to absolute welfare comparisons. For example, better-off urban consumers may choose to cut their food spending to afford certain non-food goods that are not even available to rural consumers.

We use two poverty lines, $\$ 32.74$ and $\$ 65.48$ per person per month, both at 1993 PPP, interpreted as the "\$1 a day" and "\$2 a day" lines (\$1.08 and \$2.15 more precisely). The international rural line is converted to local currency by the Bank's 1993 consumption PPP rate. We then use the ratio of the urban poverty line to the rural line from the PA (generally the one closest to 1993 if there is more than one) to obtain an urban poverty line for each country corresponding to its PPP-adjusted " $\$ 1$ a day" rural line. ${ }^{13}$

13 For example, the $\$ 1.08$ a day at 1993 Purchasing Power Parity represents 1.53 Yuan per person in China, which is equivalent to 2.42 Yuan at 1999 prices; this is the rural poverty line used for the 1999 household survey data for China. The poverty lines used by the Bank's Poverty Assessment for China imply an urban-rural differential of 1.37, so the urban poverty line for 1999 is 3.32 Yuan per person. 
Taking the international poverty line to be the rural line rather than the urban line is a somewhat arbitrary choice, although is at least broadly consistent with the original idea of the “\$1 a day" poverty line as a deliberately conservative line; indeed, the original set of poverty lines on which the World Bank's international line was based were for rural areas (Ravallion et al., 1991; World Bank, 1990). The precise line used by the Bank is $\$ 32.74$ per month $(\$ 1.08=\$ 32.74 \times 12 / 365$ per day), which is the median of the lowest 10 poverty lines in the original compilation of (largely rural) poverty lines, as documented in Ravallion et al., (1991) (although the PPPs have been updated and revised since then; see Chen and Ravallion, 2004, for details). ${ }^{14}$ By implication, our aggregate poverty count will tend to increase, given that urban poverty lines are generally above those for rural areas.

Appendix 1 provides a more formal exposition of our approach, and how it differs from past methods of measuring the extent of the urbanization of poverty.

Table 1 gives a regional summary of the poverty lines while Appendix 2 gives the urbanrural poverty line differential by country. On average, the urban poverty line is about $30 \%$ higher than the rural line. However, the numbers vary from region to region. In Eastern European and Central Asia, the urban poverty line is only $5 \%$ higher on average while in Latin America and the Caribbean it is $44 \%$ higher on average.

As can be seen in Figure 1, there is a tendency for poorer countries to have higher ratios of the urban line to the rural line; the correlation coefficient of the poverty-line ratio with the rural headcount index for $\$ 1$ a day is 0.518 in $1993(n=89)$; for the $\$ 2$ a day headcount index the correlation is 0.521 (both are significant at better than the $1 \%$ level). This is consistent with the hypothesis that internal market integration tends to improve as countries become less poor.

In all cases, the distributional data were in nominal terms, to which we applied the appropriate urban or rural poverty lines. In two-thirds of cases, the PA gives explicit urban and rural poverty lines, and we used these to construct the COL ratio and (hence) the urban poverty

14 Chen and Ravallion (2001) also estimate the expected poverty line in the poorest country, which is $\$ 1.05$ per day, although there is of course a variance around this estimate; the $95 \%$ confidence interval is $(\$ 0.88, \$ 1.24)$. 
line corresponding to the international rural line. When explicit urban-rural lines were not reported in the PA, but a deflator was applied to adjust for the urban COL differential, we "backed out" the latter from the real and nominal consumption numbers given in the micro data (in some cases this was already done in the form of a price index in the data files). When urbanrural lines (either explicit or implicit) were not available, we applied the population-weighted regional average poverty-line differential to the country in question. We used the countryspecific CPI's to adjust the urban and rural index over time. For most countries, we had little choice but to assume that the poverty line differential is constant over time; in only a few cases (though some of the largest countries, including China, India and Nigeria) did we have separate urban and rural CPIs, in order to calculate a date-specific urban-rural poverty line differential. Table 2 gives the numbers of countries in each data category at the regional level.

We were able to derive rural and urban income/consumption per capita distributions for 87 low- and middle-income countries from 208 household surveys representing $92 \%$ of the population of the developing world; Appendix 2 provides details on the country coverage and survey dates. $^{15}$ Of these, 157 are for consumption expenditure and 51 are for incomes. Within the 87 countries, 19 use only one distribution, 38 have two distributions while the rest (30) use at least three distributions over the period. ${ }^{16}$ All the household surveys used here are national coverage except Argentina and Uruguay which only cover the urban population (though $90 \%$ or more of their populations live in urban areas).

The use of a "per capita" normalization in measuring poverty is standard in the literature on developing countries; for example, virtually all of the PA's use household income or

15 It was not feasible to obtain separate rural and urban distributions for all the countries used in Chen and Ravallion (2004) since for some we only have grouped data or in a few cases there is no ruralurban identifier in the individual record data. So this is a subset of the data set we have compiled we have for 100 developing countries' income or consumption distributions from 600 + household surveys spanning 1980 to 2004, which is an updated version of the data base described in Chen and Ravallion (2004); the data are available from the PovcalNet site: http://iresearch.worldbank.org/povcalnet.

16 For some countries, we did not use all available surveys as some were not considered sufficiently comparable over time; there are examples for India, Mongolia, Cambodia, Malawi and Gambia. 
consumption per capita, as have the past international " $\$ 1$ a day" poverty counts. Although the general presumption is that there is rather little scope for economies of size in consumption for poor people, Lanjouw and Ravallion (1995) have questioned that presumption. Mean household size tends to be higher in rural than urban areas of developing countries, so introducing an allowance for economies of size in consumption will narrow the urban-rural differential in mean living standards. We expect that this would also hold for poverty measures.

Naturally the surveys are scattered over time. We estimate the poverty measures for four years spanning the range of the data, namely 1993, 1996, 1999 and 2002 . We call these the "reference years." To estimate regional poverty at a given reference year we "line up" the surveys in time using the same method described in Chen and Ravallion (2004). The latter paper also describes our interpolation method when the reference date is between two surveys.

The urban population data are from the latest available issue of the WUP in 2006 (UN, 2005). As noted in the introduction, there are undoubtedly differences in the definitions used between countries, which we can do little about here. ${ }^{17}$ The WUP estimates are based on actual enumerations whenever they are available. The WUP web site provides details on data sources and how specific cases were handled; see http://esa.un.org/unup/.

Using the household survey data, we could also draw urban population shares from each survey's internal sample weights. We found that these two sets of weights differ for some countries. This was mainly a problem in the data for Sub-Saharan Africa (SSA). To test robustness we re-calculated the estimates for SSA using the survey-based urban population shares (giving results more consistent with Chen and Ravallion, 2004). The rate of decline over time is somewhat higher using the census shares, but the difference is modest. ${ }^{18}$

\footnotetext{
17 In some cases, the WUP made adjustments to assure consistency over time, but there do not appear to have been any adjustments between countries.

18 For 1993, 1999 and 2002 the headcount indices for SSA were 51.28, 49.19 and $46.93 \%$ using census shares as compared to $51.42,49.75$ and $47.64 \%$ using the implicit weights from the survey data.
} 


\section{The urbanization of poverty 1993-2002}

Tables 3 and 4 give our aggregate results. Consistently with Claim 2, we find that rural poverty incidence is appreciably higher than urban. The " $\$ 1$ a day" rural poverty rate in 2002 of $30 \%$ is more than double the urban rate. Similarly, while we find that $70 \%$ of the rural population lives below $\$ 2$ a day, the proportion in urban areas is less than half that figure. The rural share of poverty in 2002 is $75 \%$ using the $\$ 1$ a day line, and slightly lower using the $\$ 2$ line. This is higher than the widely-used estimate of $68 \%$ obtained by Ravallion (2002) using a population-weighted aggregate of the national poverty measures. This is a non-negligible difference, representing the reclassification of over 80 million poor people from urban to rural.

Over the period as a whole, we find a 5.5\% point decline in the "\$1 a day" poverty rate, from $27.8 \%$ in 1993 to $22.3 \%$ in 2002 . This was sufficient to reduce the overall count of the number of poor by about 100 million people. However, there is a marked difference between urban and rural areas. The rural poverty rate fell much more than the rural rate. The count of 106 million fewer poor by the " $\$ 1$ a day" standard is the net effect of a decline by 153 million in the number of rural poor and an increase of 47 million in the number of urban poor. Similarly, the progress in reducing the total number of people living under $\$ 2$ a day in rural areas by 117 million came with an increase in the number of urban poor of 63 million, giving a net drop in the poverty count of only 54 million (Table 4).

Our aggregate results point to a somewhat higher overall poverty rate, and a slightly lower rate of poverty reduction than found in Chen and Ravallion (2004). On comparing our results for 1993 in Table 3 to the Chen-Ravallion estimates, using essentially the same methods but without allowing for an urban-rural differential in the cost-of-living, we find that a $\$ 1$ a day headcount index that is about about 2.2\% points higher in 1993 (27.8\% versus $25.6 \%)$ and that it declines at a rate of about $0.6 \%$ points per year, as compared to $0.7 \%$ points. The higher level is unsurprising (given that we have allowed for a higher poverty line in urban areas). The lower pace of overall poverty reduction reflects the fact that the urban headcount index for $\$ 1$ a day shows no trend decline (Table 3). Thus, we find that past methods that have ignored the urban- 
rural COL difference (including the Chen-Ravallion method) have underestimated poverty in a segment of the economy with a below average rate of poverty reduction over time, and (hence) they have slightly overestimated the overall speed of progress against poverty.

The lack of a trend in the overall urban poverty rate implies that the main proximate causes of the overall decline in the poverty rate evident in Tables 3 and 4 are (i) urban population growth (at a given urban-rural poverty rate differential) and (ii) falling poverty incidence within rural areas. To help quantify the relative importance of these factors one can decompose the change in overall poverty between 1993 and 2002 (say) as: ${ }^{19}$

$$
H_{02}-H_{93}=w^{r}\left(H_{02}^{r}-H_{93}^{r}\right)+w^{u}\left(H_{02}^{u}-H_{93}^{u}\right)+w^{s}\left(S_{02}^{u}-S_{93}^{u}\right)+\text { error }
$$

where $H_{t}$ is the aggregate headcount index, $H_{t}^{k}$ is that for sector $k=u, r$ and $t=(19) 93,(20) 02$, and (as before) $S^{u}$ is the urban population share. The first two terms on the RHS are the sector contributions (with time-invariant weights $w^{u}$ and $\left.w^{r}\right)$ while the third term $\left(w^{s}\left(S_{02}^{u}-S_{93}^{u}\right)\right)$ is the urban-rural population shift effect (weighted by $w^{s}$ ), which we call the "urbanization component." The decomposition is exact (error $=0)$ if we chose the weights $w^{k}=S_{02}^{k}$ and $w^{s}=\left(H_{93}^{u}-H_{93}^{r}\right) .^{20}$ Table 5 gives the results.

We find that $4.2 \%$ points of the $5.5 \%$ point decline in the aggregate $\$ 1$ a day poverty rate between 1993 and 2002 is attributed to lower rural poverty, 0.3\% points to lower urban poverty, and $1.0 \%$ point to urbanization. Three-quarters of the aggregate poverty reduction is accountable to falling poverty within rural areas. One-fifth is attributed to urbanization.

Note that this assessment does not allow for any indirect gains to the rural poor from urban population growth. The urbanization component in (1) can be interpreted as the direct contribution of a rising urban population share to total poverty reduction, given the initial

19 This is one of the decompositions for poverty measures proposed by Ravallion and Huppi (1991). 20 One might prefer to use the initial population shares as the weights for the sector components, but this makes very little difference (the residual is small), and the exact decomposition is neater. 
difference in urban and rural poverty measures. However, the rural poverty reduction component is also the result (in part at least) of urban population growth, notably through remittances and tighter rural labor markets. We return to this issue in section 4 .

\subsection{Are the poor urbanizing faster than the population as a whole?}

For the "\$1 a day" line, the aggregate results in Table 3 indicate that the urban share of the poor is rising (consistent with Claim 3) and that the ratio of urban poverty to total poverty incidence has risen with urbanization (implying Claim 4). The value of $H^{u} / H$ rises from 0.486 to 0.573 over $1993-2002$. The proportionate rate of growth is about $3 \%$ per year for the share of the poor living in urban areas, versus about $1 \%$ per year for the overall urban population share. ${ }^{21}$ There is naturally a smaller difference between the changes in the levels than for the (proportionate) growth rates. We find that the urban share of the " $\$ 1$ a day" poor is rising at about $0.6 \%$ points per year over $1993-2002 .^{22}$ By contrast the population as a whole is urbanizing at a rate of about $0.5 \%$ points per year over the same period. ${ }^{23}$

Using the "\$2 a day" line, we find a slightly higher proportion of the poor living in urban areas, but that this proportion has been rising at a slower pace than for the $\$ 1$ a day line; the share of the poor in urban areas is rising at about $0.3 \%$ points per year using the higher line half the absolute rate implied by the $\$ 1$ a day line. Furthermore, over the period since the late 1990s, Claim 3 is starting to look fragile for the $\$ 2$ a day line; there is a sign of a deceleration in

the urbanization of poverty in Table 4 . The ratio of urban to total poverty rose only slightly, from 0.618 to 0.620 between 1993 and 2002. Thus the rate of growth of the aggregate urban share of

21 The OLS regression coefficient of the log share of the " $\$ 1$ a day" poor in urban areas on time is $2.78 \%$ (s.e. $=0.57$ ) while for the log urban population share it is $1.17 \%(0.002)$.

22 The OLS regression coefficient of the share of the poor in urban areas for the $\$ 1.08$ /day poverty line on time is 0.591 with a standard error of 0.105 .

23 The regressions coefficient of $S^{\mathrm{u}}$ on time is 0.469 (s.e.=0.005). There is no sign of a deceleration in the rate of urbanization over this period, although there is evidence of a deceleration in urban population growth relative to prior decades; see Brockerhoff (1999). 
the poor of about $1.2 \%$ per annum over $1993-2002$ is very close to that for the population as a whole. ${ }^{24}$ Claim 4 is not supported by our results for the $\$ 2$ a day line.

So neither Claims 3 nor 4 hold up as well for the $\$ 2$ a day line as we find for $\$ 1$ a day. Urban poverty reduction has clearly played a more important role in aggregate poverty reduction using the $\$ 2$ line than the $\$ 1$ line. Of the total decline in the poverty rate for the higher line of $8.9 \%$ points, $4.9 \%$ is attributed to rural poverty reduction ( $55 \%$ of the total), $2.3 \%$ to urban, and $1.6 \%$ to the population shift effect (based on equation (1)).

It is of interest to see what happens if we drop China from these calculations, given its size and the fact that China is unusual in a number of respects, notably in the low share of the poor living in urban areas and the slower pace in the urbanization of poverty compared to other developing countries. Tables 3 and 4 also give the aggregate results excluding China. As expected, we then find a higher urban share of the poor. What is more notable is that we now find that $H^{u} / H$ is rising over time using both poverty lines, supporting Claim 4; excluding China, $H^{u} / H$ rises from 0.580 to 0.651 for $\$ 1$ and 0.670 to 0.699 for $\$ 2$ a day.

We can also assess the validity of Claims 3 and 4 using the country-level estimates underlying Tables 3 and 4. By definition, the share of the poor living in urban areas is $P^{u}\left(S^{u}\right) \equiv\left(H^{u} / H\right) S^{u}$, where $H^{u} / H$ is taken to be a function of the urban share of the population, $S^{u} ; P^{u}\left(S^{u}\right)$ is the poverty urbanization curve (PUC) of Ravallion (2002) where the derivation and properties is discussed further. Log differentiating with respect to time, the growth rate in the urban share of the poor is:

$$
\frac{\partial \ln P^{u}\left(S^{u}\right)}{\partial t}=\left(1+\frac{\partial \ln H^{u} / H}{\partial \ln S^{u}}\right) \frac{\partial \ln S^{u}}{\partial t}
$$

We can estimate the elasticity, $\partial \ln \left(H^{u} / H\right) / \partial \ln S^{u}$, from the country-level estimates underlying Tables 3 and 4. The estimated elasticity is 0.304 (s.e. $=0.075 ; n=348)$ for the $\$ 1$ a day line and

24 The regression coefficient of the log share of the poor in urban areas for the $\$ 2 /$ day poverty line on time is $1.14 \%$ with a standard error of 0.37 . 
$0.127(0.0230 ; \mathrm{n}=348)$ for the $\$ 2$ line. The fact that these elasticities are significantly positive implies that the poor urbanize faster than the population as a whole $\left(\partial \ln P^{u}\left(S^{u}\right) / \partial t>\partial \ln S / \partial t\right)$. While Claim 4 is confirmed, the difference in growth rates is small, especially for the $\$ 2$ a day line. Slightly higher elasticities are obtained if we allow for regional fixed effects; then the estimated elasticities increase to $0.398(0.100)$ and $0.211(0.040)$ for the $\$ 1$ and $\$ 2$ lines respectively. ${ }^{25}$ (There was no sign of time effects.)

There are two proximate reasons why the poor are urbanizing faster: the first is that the proportionate difference between urban and rural poverty rates rises with urbanization, and the second is the size of the initial gap in poverty rates between the two sectors. This can be verified on noting that:

$$
\frac{\partial \ln H^{u} / H}{\partial \ln S^{u}}=\frac{S^{u}\left(H^{r}-H^{u}\right)}{H}+\frac{\left(1-S^{u}\right) H^{r}}{H} \frac{\partial \ln H^{u} / H^{r}}{\partial \ln S^{u}}
$$

Using regressions of the $\log$ poverty rate differential $\left(\ln \left(H^{u} / H^{r}\right)\right)$ on the $\log$ urban population share using the pooled data, we cannot reject the null hypothesis that $\partial \ln \left(H^{u} / H^{r}\right) / \partial \ln S^{u}=0$ (the t-ratio is 1.21 for $\$ 1$ and -0.001 for $\$ 2$ ). However, when we allow for regional effects we find that the second component is positive and significant; for the $\$ 1$ a day headcount index, the regression coefficient is $0.268(\mathrm{t}=2.23)$, while it is $0.140(\mathrm{t}=2.57)$ for $\$ 2$ a day. This suggests that both factors are at work.

\subsection{Regional differences}

It is evident from Tables 3 and 4 that Claim 2 holds in all regions for both lines, although there are notable differences across regions in the extent of the disparity in poverty rates between urban and rural areas. In 2002, the rural headcount index for East Asia was nine times higher than the urban index, but only 16\% higher in South Asia, the region with the lowest relative difference in poverty rates between the two sectors. The contrast between China and India is

25 Note that the fact that these are un-weighted regressions entails that China gets a lower weight than the population-weighted aggregates in Tables 3 and 4; as we have already seen the aggregate results without China are more consistent with Claims 3 and 4, and with these regressions. 
particularly striking, with an urban poverty rate in China in 2002 that is barely $4 \%$ of the rural rate, while it is $86 \%$ for India. Urban poverty incidence in China is unusually low relative to rural, although problems in the available data for China are probably leading us to underestimate the urban share of the poor in that country. ${ }^{26}$

The regional differences in the urbanization of poverty are clear in Figure 2, plotting the urban share of the poor by region. The share is lowest in East Asia, due in large part to China. The urban share of the poor is highest in LAC, which is the only region in which more of the " $\$ 1$ a day" poor live in urban than rural areas (the switch occurred in the mid-1990s). For LAC, almost two-thirds of the $\$ 2$ a day poor live in urban areas.

South Asia and SSA are clearly the regions with highest urbanization of poverty at given overall urbanization, due to their relatively high urban poverty rates relative to rural; these are also the regions with the highest overall poverty rates. In $2002,44 \%$ of the world's urban poor by the $\$ 1$ a day line are found in South Asia, and 35\% are found in SSA; these proportions fall appreciably when one focuses on the $\$ 2$ a day line, for which $39 \%$ and $22 \%$ of the urban poor are found in South Asia and SSA respectively.

There are other notable regional differences. In the aggregate and in most regions, poverty incidence fell in both sectors over the period as a whole (though with greater progress against rural poverty in the aggregate). LAC and SSA are exceptions. There rising urban poverty came with falling rural poverty. The (poverty-reducing) population shift and rural components of equation (1) for LAC and SSA were offset by the (poverty-increasing) urban component.

While the urban poverty rate for the developing world as a whole was relatively stagnant over time for $\$ 1$ a day, this is not what we find in all regions. Indeed, the urban poverty rate is

26 The main problem is that (until recently) the sample frame for China's national urban and rural surveys has been based on the registration system rather than street addresses. Thus recent migrants to urban areas are thus likely to be undercounted in the urban surveys since their registration will still be rural. On the (plausible) assumption that rural migrants are poorer than the average urban resident, we will underestimate urban poverty incidence. 
falling relative to the national rate in both East Asia and ECA, attenuating the urbanization of poverty; indeed, in ECA the urban share of the poor is actually falling over time - a "ruralization" of poverty - even while the urban share of the total population has risen, though only slightly. (There is the hint of a ruralization of $\$ 2$ a day poverty in East Asia from the late 1990s, again due to China.) The ruralization of poverty in ECA is not surprising, as it is consistent with other evidence suggesting that the economic transition process in this region has favored urban areas over rural areas (World Bank, 2005). This has also been the case in China since the mid-1990s (Ravallion and Chen, 2007).

South Asia shows no trend in either direction in the urban poverty rate relative to the national rate, and the region has also had a relatively low overall urbanization rate, with little sign of a trend increase in the urban share of the poor. The population shift component of the decomposition in equation (1) is also relatively less important in South Asia.

The urban poverty rate relative to the national rate has shown no clear trend in SubSaharan Africa, although rapid urbanization of the population as a whole has meant that a rising share of the poor are living in urban areas.

Using the country level estimates underlying Tables 3 and 4 we can also estimate the elasticity of $H^{u} / H$ to $S^{u}$ by region. Table 7 gives the results. Two regions stand out as exceptions to Claim 4: ECA and MNA. In ECA we find that the elasticity is not significantly different from zero in the country-level data set; this is also true for MNA using \$2 a day, but we find a significant negative elasticity for $\$ 1$ a day, implying that the poor are urbanizing at a significantly lower rate than the population as a whole.

\subsection{Urban and rural poverty gaps}

So far we have focused on the headcount index. While this is the most common measure in practice, it has the well-known conceptual drawback that it does not reflect changes in living standards below the poverty line. Table 8 gives the poverty gap (PG) indices for both poverty lines. The overall patterns are similar to Tables 3 and 4, and most of the same comments apply. The urban share of the total poverty gap - the urban poverty gap times the urban population 
share divided by the total (urban + rural) poverty gap — has risen over time, with about threequarters of the overall poverty gap found in rural areas in 2002 (slightly lower for \$1 a day than \$2). One difference is that the $\$ 1$ a day poverty gap in South Asia is not becoming any more urban over time, though this is evident for the higher poverty line.

While our results for both the headcount index and poverty gap index (and both poverty lines) confirm Claim 2, there is a qualification to be noted. Among those living below the poverty line, the mean poverty gap turns out to be higher in urban areas than in rural areas, using the $\$ 1$ a day line. The mean income of those living below this line in 2002 was $\$ 0.73$ in urban areas as compared to $\$ 0.77$ in rural areas (combining Tables 8 and 3). ${ }^{27}$ The ranking is the same in other years, but switches at the $\$ 2$ a day poverty line.

\section{Population urbanization and poverty reduction}

We do not attempt a causal analysis of the poverty impacts of urbanization, but we can offer some empirical observations from our data that are at least consistent with Claim 5.

It is clear from Table 3 that different regions are urbanizing at rather different rates over time. These differences are correlated with rates of poverty reduction. Using the country-level estimates for all years, Figure 3 plots of the $\$ 1$ and $\$ 2$ a day poverty rates against the urban population shares. There is a strong negative correlation. Figure 4 gives the corresponding figures with a split of the urban and rural sectors. We see that both urban and rural poverty rates tend to be lower at higher urban population shares, but there is also a clear sign of convergence, such that the absolute gap between the urban and rural poverty rates tends to be lower at higher levels of urbanization; the regression coefficient of $H^{u}-H^{r}$ on $S^{u}$ is 0.241 (s.e. $=0.033 ; \mathrm{n}=340$ ) for the $\$ 1$ a day line and $0.262($ s.e. $=0.036 ; n=340)$ for the $\$ 2$ line. $^{28}$

27 This calculation uses the fact that the mean income of the poor is given by $Z(1-P G / H)$.

28 There is also evidence that the child health advantages of cities over towns and villages (as measured by infant mortality rates) have tended to diminish over time (Brockerhoff and Brennan, 1998). 
Figures 3 and 4 could be deceptive if population urbanization is correlated with country or regional characteristics relevant to poverty. To address this concern we use a "difference-indifference" estimator, whereby the urban and rural poverty rates are regressed on the urban population share including additive fixed effects (a dummy variable for each region or country), i.e., the mean level of poverty at a given urban population share is allowed to vary by region or country; Table 6 gives the results. ${ }^{29}$ Both poverty measures tend to decline as the urban population share rises, although the effect are generally smaller (but more significant) for the country data. ${ }^{30}$

Amongst the six regions of the developing world, SSA also stands out as an exception to our finding that urbanization has come with falling overall poverty. Splitting the regression coefficient of the aggregate headcount index for pooled regions and dates on the urban population share between SSA and the rest (with regional fixed effects) we find that the coefficient is $-0.396(0.335)$ for SSA versus $-1.115(0.432)$ for non-SSA regions. The urbanization effect is on rural poverty, with no effect on urban poverty in SSA and only a small effect in non-SSA. ${ }^{31}$

One can question a strict causal interpretation of these regressions. It is unlikely to be population urbanization per se that is leading to lower poverty, but rather the economic opportunities that can come with urbanization, both directly (to migrants) and indirectly (to non-

29 As a further test, we repeated the regressions in Table 6 allowing for an independent time trend, but we found a similar pattern, suggesting that the significant regression coefficients on urban population share for both national and rural poverty; the urbanization effect is not just picking up a trend reduction in poverty. The regression coefficients on the urban population share were $-0.934(0.386),-1.107(0.462)$ and $-0.206(0.161)$ for the national, rural and urban $\$ 1$ a day headcount indices respectively.

30 For completeness, Table 6 gives the regression for the national poverty measures, but it should be noted that an identity links the urban and rural measures and urban population share to the national measure. A consistent regression for the national poverty measure would include a squared term in the urban population share; we also tested this specification, and the results were consistent with expectations.

31 For rural poverty the regression coefficient is $-0.407(0.278)$ in SSA versus $-1.344(0.515)$ in nonSSA. For urban poverty the corresponding coefficients are $-0.014(0.473)$ and $-0.271(0.143)$. 
migrants in rural areas). All we can reasonably claim from these results is that the data are at least consistent with the view that urbanization plays a positive role in overall poverty reduction.

While the precise channels through which population urbanization influences poverty reduction are a subject for future research, one question of interest can be addressed relatively easily: Do we find that population urbanization had an effect on the pace of poverty reduction independently of overall growth in mean consumption? In other words, is there evidence of a distributional effect of urbanization, or is its effect transmitted entirely through economic growth? One reason to expect a distributional effect draws on the literature in development economics on the Kuznets Hypothesis. Some of our empirical results so far do not accord well with the assumptions typically used to motivate the KH. The now classic formulation in the literature posits what is sometimes called a "Kuznets process" of migration whereby a representative slice of the rural distribution is transformed into a representative slice of the urban distribution; yet we find signs that the urbanization process has changed distribution within urban areas. Nonetheless, it is of interests to see if there any signs of a distributional effect of urbanization, as implied by the KH. To do so we regress the log national headcount index on a quadratic function of both the log mean and the urban population share:

$$
\ln H_{i t}=\alpha+\beta_{1} \ln \mu_{i t}+\beta_{2}\left(\ln \mu_{i t}\right)^{2}+\gamma_{1} S_{i t}^{u}+\gamma_{2} S_{i t}^{u 2}+\delta S_{i t}^{u} \ln \mu_{i t}+\eta_{i}+\varepsilon_{i t}
$$

where the overall mean is $\mu_{t}=n_{t}^{r} \mu_{t}^{r}+n_{t}^{u} \mu_{t}^{u}$, where $\mu_{t}^{i}$ is the mean for sector $i=r, u$ for rural and urban areas, and $\eta_{i}$ is a country fixed effect. This can be thought of as a test for the KH in which the relevant "inequality" measure is the distributional component of poverty. ${ }^{32}$

Table 9 gives the results. The estimates for the $\beta$ parameters are (highly) significant. We also find a (mildly) significant positive interaction effect between the log mean and the urban population share, implying that urbanization tends to reduce the growth elasticity of poverty

32 The presence of a country effect in this test is important; for further discussion, and evidence that the KH does not hold when one allows for country effects see Bruno et al. (1998); for a good review of the evidence on the KH see Fields (2001, Chapter 3). 
reduction (prob. $=0.015$ for $\$ 1$ and 0.018 for $\$ 2$ ). However, we cannot reject the null hypotheses that $\gamma_{1}=\gamma_{2}=\delta=0$ for either " $\$ 1$ a day" (prob. $=0.085$ ) or " $\$ 2$ a day" (prob. $\left.=0.160\right)$.

These tests suggest that the main channel connecting population urbanization to poverty is through aggregate economic growth. This was also true for each region separately except for SSA, where for the $\$ 2$ a day line we could reject the above null, though only at the $2 \%$ level (prob. $=0.0176)$.

\section{On the future urbanization of poverty}

The latest WUP predicts that the urban share of the population of the developing world will reach $60 \%$ by 2030 (UN, 2005). Critics of the WUP forecasting methods have argued that they are likely to overestimate the pace of future urbanization (National Research Council, 2003; Bocquier, 2005). This is suggested by Cohen's (2004) observation that the urban population of the developing world in 2000 was appreciably lower than the WUP predictions for that year made in both 1990 and 1980. Bocquier's (2005) alternative forecasting method predicts a much slower pace of urbanization, with the urban population share rising to only $49 \%$ in $2030 .{ }^{33}$

There are reasons to be skeptical of all such forecasts, but this is not the place to dwell on such concerns. All we want to do here is to see what implications current forecasts for urban population growth hold for future trends in the urbanization of poverty, in the light of our new data set. To do so we need to link the growth rate of the urban population to the urbanization of poverty. That link is directly provided by the PUC, $P^{u}\left(S^{u}\right)$. Ravallion (2002) proposes the following cubic specification for the PUC:

$$
P^{u}\left(S^{u}\right)=\left[1+\beta\left(1-S^{u}\right)+\gamma\left(1-S^{u}\right)^{2}\right] S^{u}
$$

\footnotetext{
33 The methodological issue raised by Bocquier relates to the extent of nonlinearity in the relationship between the urban-rural growth difference and the urban population share; the UN's methods assume linearity; Bocquier presents evidence suggesting that it is a nonlinear relationship, which he then allows for in his own forecasting method.
} 
This has the desired theoretical properties - notably that the function $P^{u}($.$) maps from [0,1]$ to $[0,1]$ - and sufficient flexibility to represent the data.

On adding an error term and estimating a pooled model over all four years, with different parameters for each year, we could not reject the null hypothesis that $\beta+\gamma=0$ in equation (5). Imposing this restriction we obtained (with the White standard error in parentheses):

$$
P^{u}\left(S_{i t}^{u}\right)=\left[1-\underset{(0.113)}{1.449}\left(1-S_{i t}^{u}\right) S_{i t}^{u}\right] S_{i t}^{u}+\hat{\varepsilon}_{i t} \mathrm{n}=336 ; \mathrm{R}^{2}=0.460
$$

We also allowed $\beta$ to vary by year, but could not reject the null hypothesis that the parameter is constant over time. ${ }^{34}$ Figure 5(a) plots the data and fitted values based on (6).

For the $\$ 2$ poverty line, the coefficient on the squared term was not significantly different from zero ( $\mathrm{t}=1.115$ ). Imposing this restriction we settled on the following model for the $\$ 2$ line:

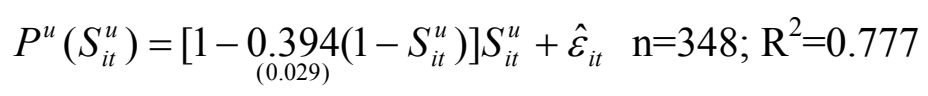

Again, we could not reject the null of parameter constancy over time. ${ }^{35}$ Figure 5(b) plots the data and fitted values based on equation (7).

The fit is noticeably better for the $\$ 2$ line. The $\$ 1$ a day measures are very low for some middle-income countries in the sample, and the accuracy of our estimates of the share of poverty in urban areas is questionable at low levels of poverty. As one test for robustness we reestimated equation (6) on a truncated sample for which the $\$ 1$ a day headcount index exceeded $2 \%$. The overall fit improved appreciably, with $\mathrm{R}^{2}$ rising to 0.615 and the estimated coefficient was -1.196 (s.e. $=0.107 ; \mathrm{n}=270)$.

The intertemporal stability of the PUC gives us some confidence in using it as a forecasting tool, for given projections of the urban population share. Recall that the WUP predicts that the urban population share for the developing world will reach $60 \%$ by 2030 (UN,

\footnotetext{
34 The parameter estimates were -1.306 (s.e. $=0.245),-1.494(0.226),-1.581(0.217)$ and -1.411 (0.220) for 1993, 1996, 1999 and 2002 respectively.

35 The estimates were $-0.413(0.055),-0.389(0.055),-0.391(0.055)$ and $-0.382(0.055)$ for 1993 , 1996, 1999 and 2002 respectively.
} 
2005). If poverty urbanizes in the future consistently with the relationship modeled above, then the urban share of " $\$ 1$ a day" poverty will reach 39\% at that date, with a standard error of $1.6 \%$. (This rises to $43 \%$ for the truncated sample with poverty rates over $2 \%$.) For the higher poverty line, the urban share of the poor will be $51 \%$ by 2030 with a standard error of $0.7 \%$.

For the $\$ 1$ a day line, these estimates are very close to what one obtains by the simplest linear extrapolation. At the rate of increase in the urban share of the world's " $\$ 1$ a day" poor of $0.6 \%$ points per year implied by Table 3 , the share will rise from $25 \%$ in 2002 to $42 \%$ by 2030 . A majority of the poor will be found in rural areas until about 2040. However, at the pace of

urbanization found for the $\$ 2$ poverty rate that we find in Table 4, a majority of the poor will live in rural areas for another 80 years or so! The signs of deceleration in the urbanization of the $\$ 2$ a day poor in Table 4 also point to a slower future rate than suggested by the above calculations based on the WUP projections and our PUC's.

Systematic errors in the UN's projections for the urban population share will, of course, bias these forecasts for the future urbanization of poverty. As already noted, the critical assessments of the UN's forecasts have argued that they are likely to overestimate the pace of future urbanization. The alternative forecasts by Bocquier (2005) predict that the urban population share will only rise to $49 \%$ by 2030 . Inserting this into our PUC implies that the urban share of the "\$1 a day" poor will rise to only 31\% by that date (standard error of $1.4 \%$ ), while for the $\$ 2$ line it rises to $39 \%$ (s.e. $=0.7 \%$ ).

These projections should clearly not be taken too seriously. Narrowing down the range of estimates would certainly require a credible economic model, since the pace of urbanization will undoubtedly depend on the extent and pattern of future economic growth. However, from what we currently know, it appears very likely that the bulk of the poor will still be living in rural areas for at least a few decades to come.

\section{Conclusions}

Widely heard concerns about the urbanization of poverty in the developing world have been neither well informed by data nor cognizant of the broader economic role of urbanization in 
the process of overall poverty reduction. To help address these issues, we have provided new estimates of the urban-rural breakdown of absolute poverty measures for the developing world, drawing on over 200 household surveys for about 90 countries, and exploiting the World Bank's Poverty Assessments for guidance on the urban-rural cost-of-living differential facing poor people, to supplement existing estimates of the Purchasing Power Parity exchange rates for consumption.

We estimate that about three-quarters of the developing world's poor still live in rural areas, when assessed by international poverty lines that aim to have a constant real value (between countries and between urban and rural areas within countries). Poverty is clearly becoming more urban, although our results suggest that it will be many decades before a majority of the developing world's poor live in urban areas.

The poor are urbanizing faster than the population as a whole, reflecting a lower-thanaverage pace of urban poverty reduction. One's concern about the seemingly low pace of urban poverty reduction in much of the developing world must be relieved by the fact that it has come with more rapid progress against rural poverty. Over 1993-2002, while 50 million people were added to the count of $\$ 1$ a day poor in urban areas, the aggregate count of the poor fell by about 100 million, thanks to a decline of 150 million in the number of rural poor.

Although our analysis has been descriptive, rather than attempting to draw causal inferences, the empirical findings are broadly consistent with the view that the urbanization process has played a quantitatively-important positive role in overall poverty reduction, by providing new opportunities to rural out-migrants (some of whom escape poverty in the process) and through the second-round impact of urbanization on the living standards of those who remain in rural areas. What we see here is suggestive of a compositional effect on the changing urban population, whereby the slowing of urban poverty reduction is the "other side of the coin" to what is in large part a poverty-reducing process of urbanization. Nor do we find any sign of adverse distributional effects of urbanization; instead it seems that the main channel linking population urbanization to poverty reduction is the rate of economic growth. Yes, the poor are 
gravitating to towns and cities, but more rapid poverty reduction through economic growth will probably entail an even faster pace of urbanization.

We find some marked regional differences in a number of respects. The majority of Latin America's poor live in urban areas, while it is less than $10 \%$ in East Asia (due mainly to China). The pattern of falling overall poverty with urbanization is far less evident in SubSaharan Africa, where the population (including the poor) has been urbanizing, yet with little reduction in aggregate poverty. There are also exceptions at the regional level to the overall pattern of poverty's urbanization; indeed, we find signs of a ruralization of poverty in China and in Eastern Europe and Central Asia.

Our results also have implications for assessments of overall progress against poverty. Compared to past estimates ignoring urban-rural cost-of-living differences, we find a somewhat higher aggregate poverty count for the world, and a somewhat lower pace of poverty reduction. These differences stem from the higher cost-of-living and the slower pace of poverty reduction in urban areas revealed by our study. 


\section{References}

Ackland, Robert, Steve Dowrick and Benoit Freyens, 2006. "Measuring Global Poverty: Why PPP Methods Matter," mimeo, Research School of Social Sciences, Australian National University.

Anand, Sudhir and S.M. Ravi Kanbur, 1993. "The Kuznets Process and the Inequality-

Development Relationship," Journal of Development Economics 40:25-52.

Atkinson, Anthony B., 1987, "On the Measurement of Poverty," Econometrica 55: 749-764.

Banerjee, Abhijit and Thomas Piketty, 2005, “Top Indian Incomes, 1922-2000”, The World Bank Economic Review, 19: 1-20.

Bhalla, Surjit, 2002. Imagine There's No Country: Poverty, Inequality and Growth in the Era of Globalization, Institute for International Economics, Washington DC.

Bocquier, Philippe, 2005, "World Population Prospects: An Alternative to the UN Model of Projection Compatible with Urban Transition Theory," Demographic Research 12(9): 197-236.

Bourguignon, François and Christian Morrisson. 2002. "Inequality Among World Citizens: 1820-1992”, American Economic Review, 92 (4): 727-744.

Brockerhoff, Martin. 1999. "Urban Growth in Developing Countries: A Review of Projections and Predictions," Population and Development Review 25(4): 757-778.

Brockerhoff, Martin and Ellen Brennan. 1998. "The Poverty of Cities in Developing Regions," Population and Development Review 24(1): 75-114.

Bruno, Michael, Martin Ravallion and Lyn Squire. 1998. "Equity and Growth in Developing Countries: Old and New Perspectives on the Policy Issues," in Income Distribution and High-Quality Growth (edited by Vito Tanzi and Ke-young Chu), Cambridge, Mass: MIT Press.

Chen, Shaohua and Ravallion, Martin, 2001, "How Did the World's Poor fare in the 1990s?", Review of Income and Wealth, 47(3): 283-300. and , 2004, "How Have the World's Poorest Fared Since the 
Early 1980s?", World Bank Research Observer, 19(2): 141-170.

Cohen, B., 2004, "Urban Growth in Developing Countries: A Review of Current Trends and a Caution Regarding Existing Forecasts," World Development 32(1): 35-51.

Fields, Gary S., 2001, Distribution and Development. New York: Russell Sage Foundation.

Goldstein, Sidney, 1990, “Urbanization in China, 1982-87: Effects of Migration and Reclassification," Population and Development Review 16(4): 673-701.

Groves, R.E., Couper, M.P., 1998, Nonresponse in Household Interview Surveys. Wiley, New York.

Korinek, Anton, Johan Mistiaen and Martin Ravallion, 2006. "Survey Nonresponse and the Distribution of Income.” Journal of Economic Inequality, 4(2): 33-55.

Kuznets, Simon, 1955, "Economic Growth and Income Inequality," American Economic Review 45:1-28.

Lanjouw, Peter and Martin Ravallion, 1995, "Poverty and Household Size," Economic Journal, 105: $1415-1435$.

Panel on Urban Population Dynamics, National Research Council, 2003, Cities Transformed: Demographic Change and its Implications for the Developing World, Washington DC: National Academies Press.

Piel, Gerard, 1997, “The Urbanization of Poverty Worldwide,” Challenge 40(1): 58-68.

Ravallion, Martin, 1994, Poverty Comparisons, Harwood Academic Press, Shur, Switzerland. , 1998. Poverty Lines in Theory and Practice. Living Standards Measurement Study Working Paper No. 133. Washington, DC: World Bank. ,2002, "On the Urbanization of Poverty," Journal of Development Economics 68: 435-442.

Ravallion, Martin and Shaohua Chen, 2007, "China's (Uneven) progress Against Poverty," Journal of Development Economics, 82(1): 1-42. 
Ravallion, Martin, Gaurav Datt and Dominique van de Walle, 1991, “Quantifying Absolute Poverty in the Developing World", Review of Income and Wealth 37: $345-361$

Ravallion, Martin and Monika Huppi, 1991, "Measuring Changes in Poverty: A Methodological Case Study of Indonesia During an Adjustment Period," World Bank Economic Review, 5: $57-82$

Ravallion, Martin and Michael Lokshin, 2005, “Who Cares about Relative Deprivation?” Policy Research Working Paper 3782, World Bank, Washington DC.

Sala-i-Martin, Xavier. 2006. “The World Distribution of Income: Falling Poverty and Convergence. Period," Quarterly Journal of Economics, 121(2): 351-397.

United Nations, 2005. World Urbanization Prospects: The 2005Revision, Population Division, Department of Economic and Social Affairs. http://www.un.org/esa/population/

World Bank, 1990, World Development Report: Poverty. New York: Oxford University Press. , 2005, Growth, Poverty and Inequality: Eastern Europe and the Former Soviet Union, Washington DC: World Bank. ,2006, World Development Indicators. Washington DC: World Bank. 
Figure 1: Plot of urban-rural poverty line differential against rural headcount index

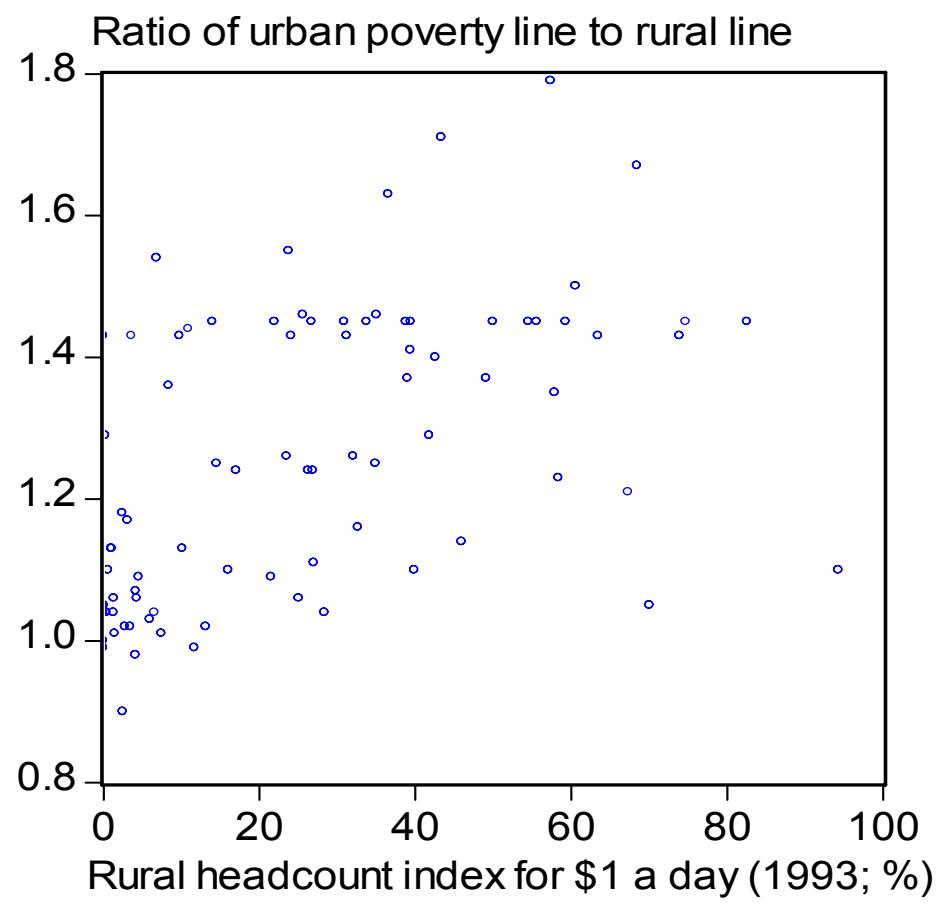


Figure 2: Urbanization of poverty by region

(a) "\$1 a day" poverty line

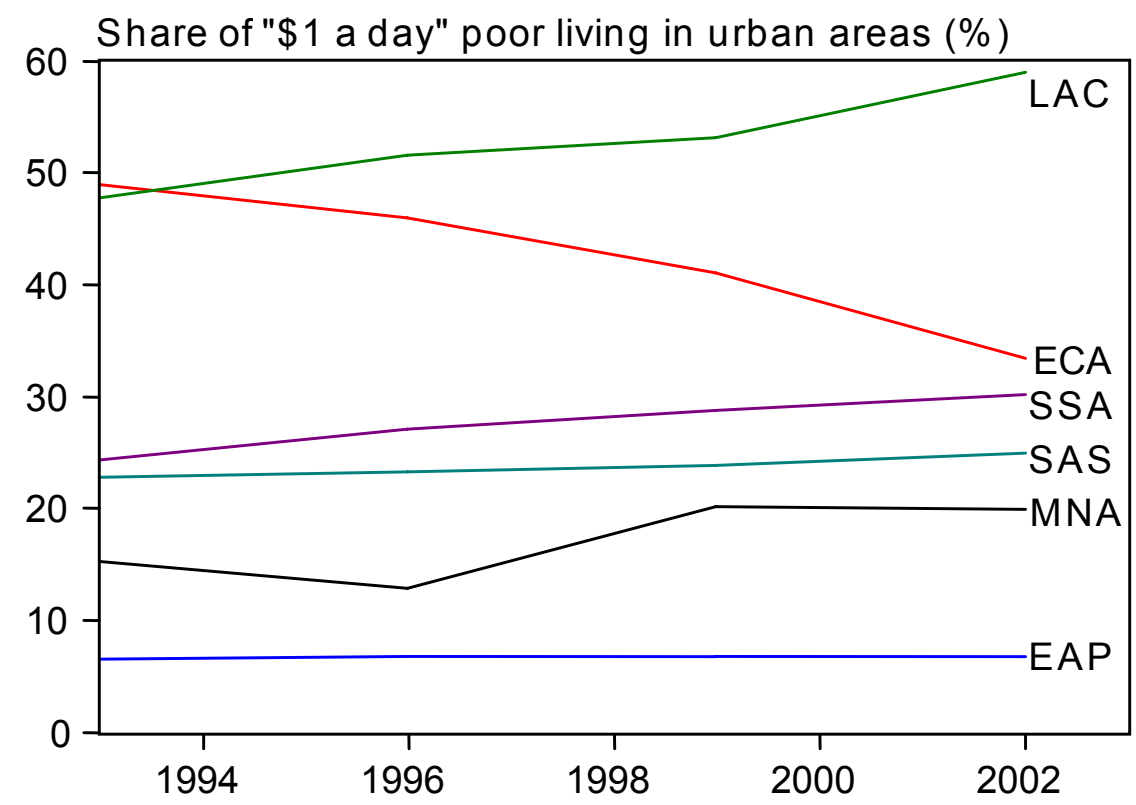

(b) "\$2 a day" poverty line

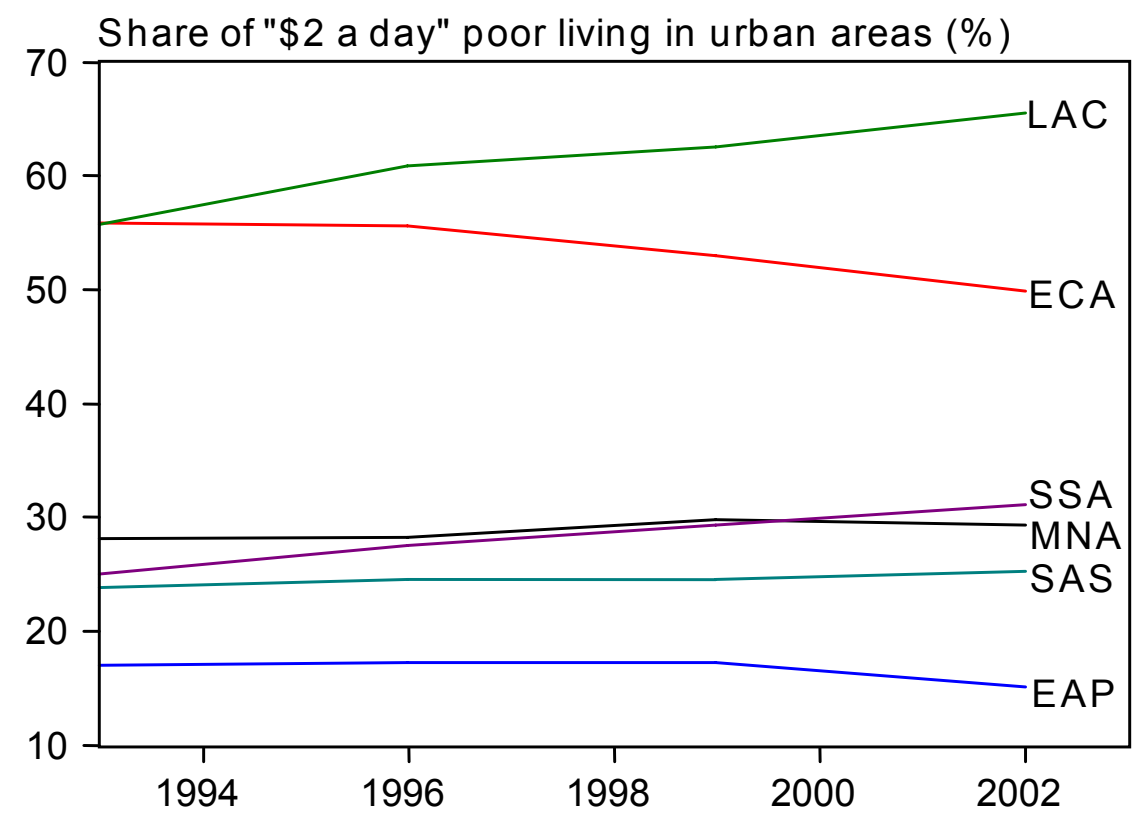


Figure 3: National headcount indices plotted against urban population share (countries and dates pooled)

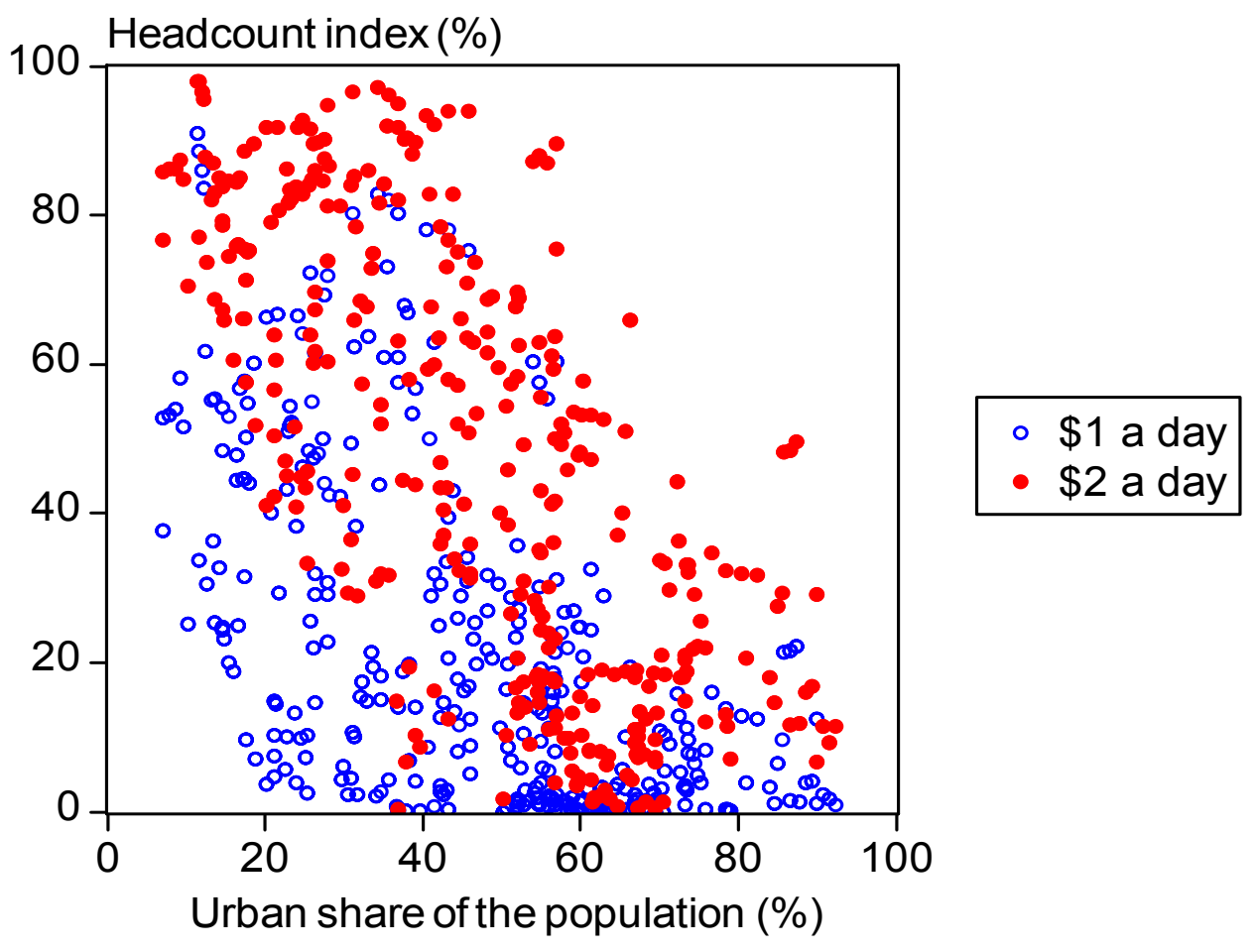


Figure 4: Urban and rural headcount indices plotted against urban population shares

(a) "\$1 a day" poverty line

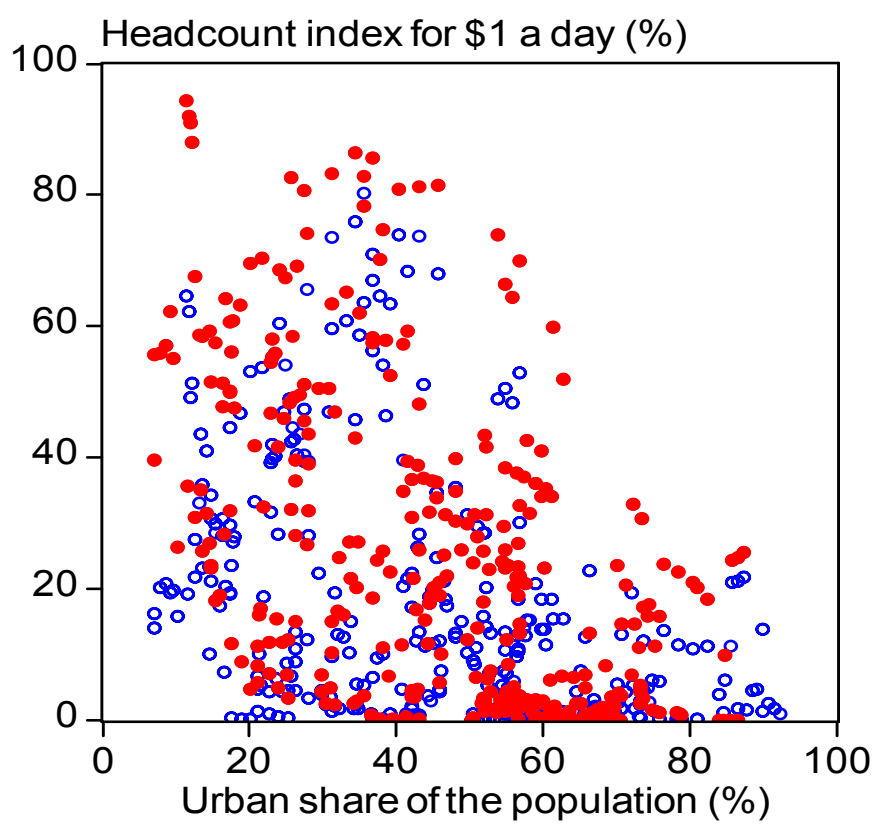

- Urban areas

- Rural areas

(b) "\$2 a day" poverty line

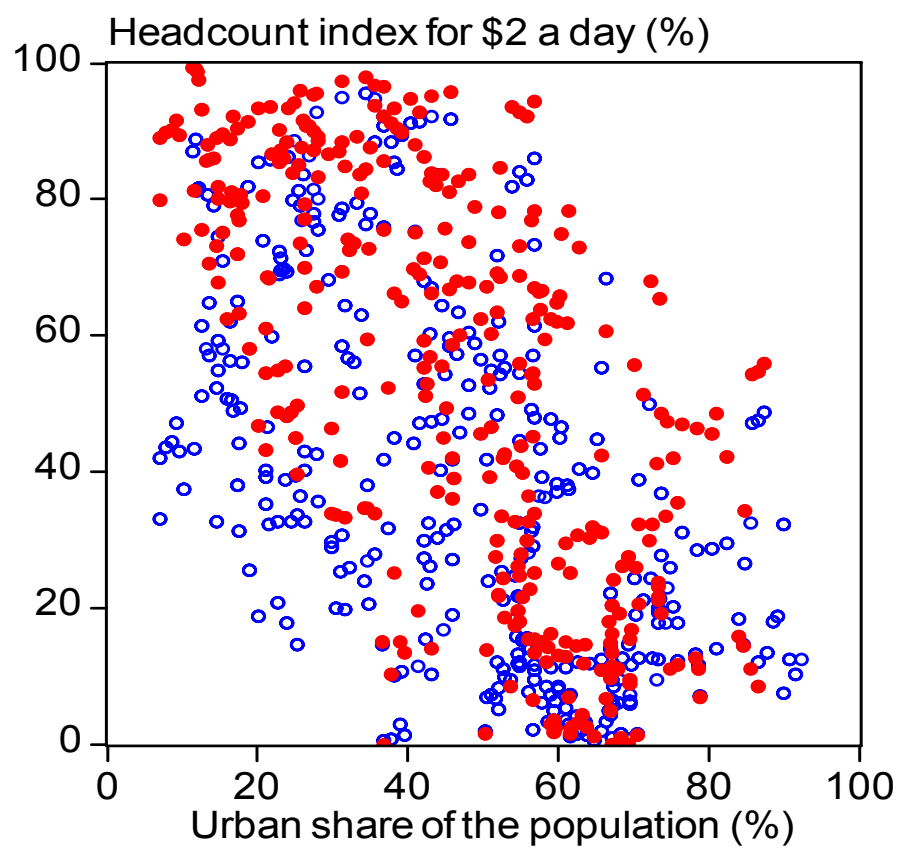

- Urban areas

- Rural areas 
Figure 5: Urban share of the poor against urban population share (countries and years)

(a) "\$1 a day" poverty line

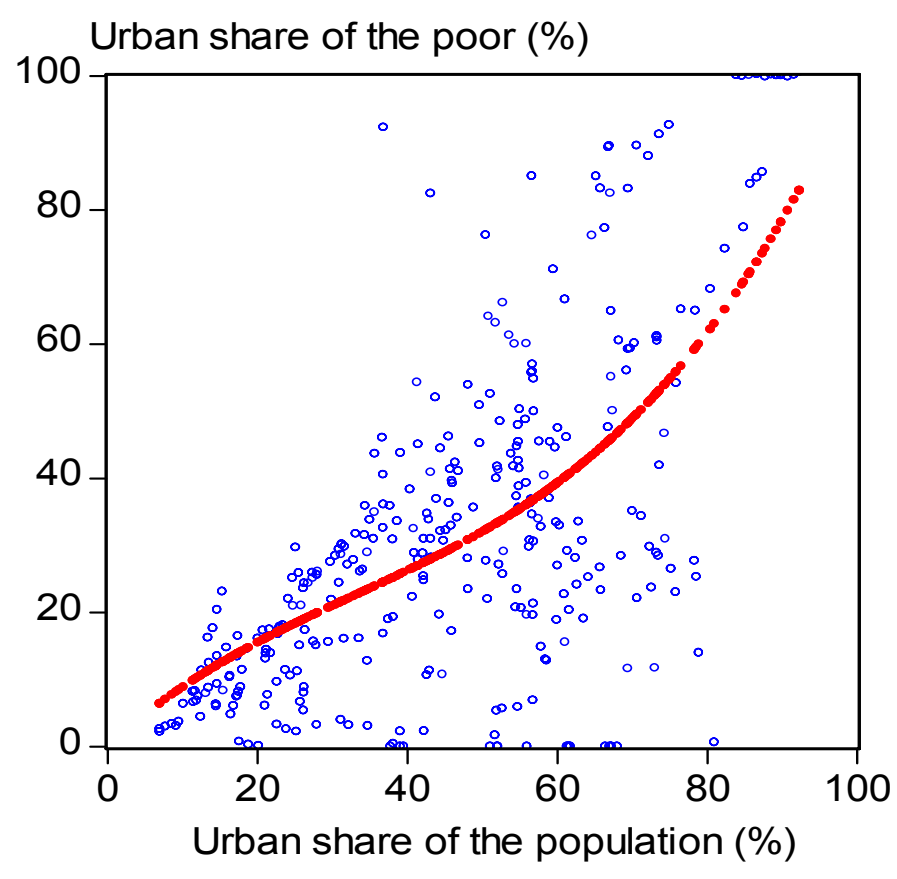

(b) "\$2 a day" poverty line

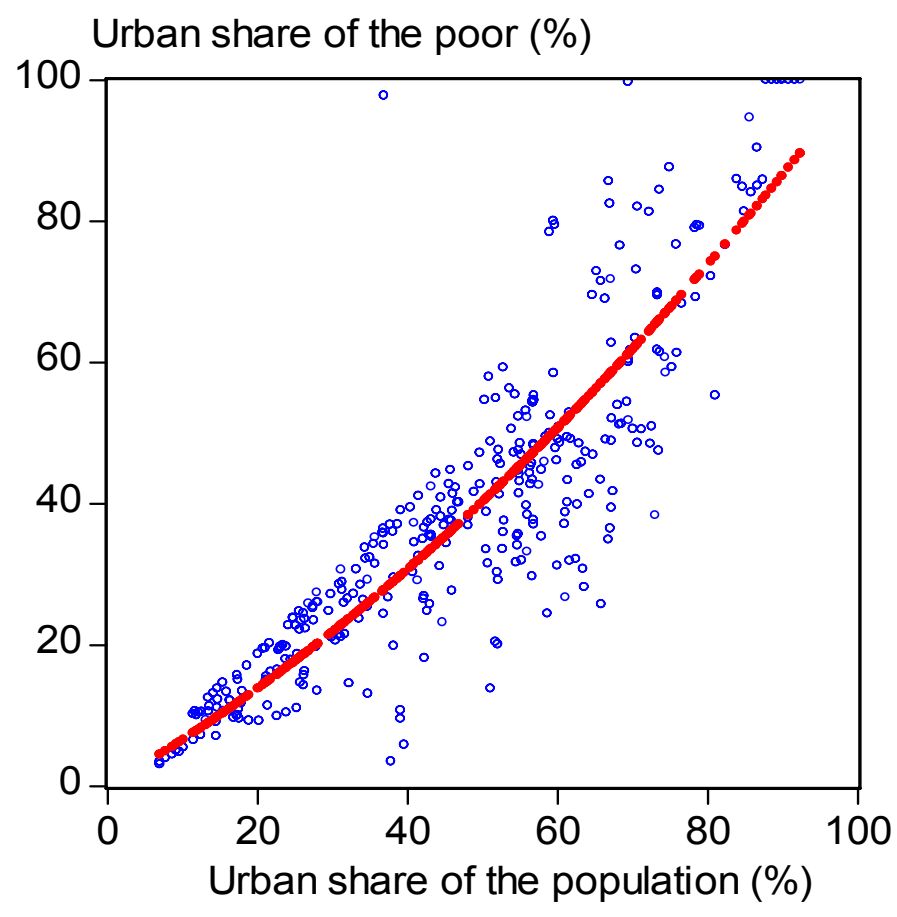


Table 1: Population-weighted urban poverty lines in 1993 PPP

Urban poverty line (\$/day; 1993 PPP)

corresponding to a rural line of:

$\$ 1.08$

$\$ 2.15$

East-Asia and Pacific

(EAP)

1.40

2.79

Eastern-Europe and

Central Asia (ECA)

$1.13 \quad 2.27$

Latin America and

Caribbean (LAC)

$1.55 \quad 3.10$

Middle East and North

Africa (MNA)

$\begin{array}{ll}1.19 & 2.37\end{array}$

South Asia (SAS)

$\begin{array}{ll}1.40 & 2.79\end{array}$

Sub-Saharan Africa (SSA)

1.39

2.77

Total

1.39

2.79

Table 2: Number of countries by type of data

\begin{tabular}{lcccc}
\hline Region & $\begin{array}{c}\text { Countries with } \\
\text { rural/urban } \\
\text { distribution data }\end{array}$ & $\begin{array}{c}\text { Countries with urban-rural poverty lines } \\
\text { Explicit } \\
\text { in PA }\end{array}$ & $\begin{array}{c}\text { Implicit in } \\
\text { data files }\end{array}$ & $\begin{array}{c}\text { No. countries for } \\
\text { which regional } \\
\text { mean is used }\end{array}$ \\
\hline EAP & 8 & 7 & 0 & 1 \\
ECA & 21 & 12 & 19 & 1 \\
LAC & 21 & 12 & 0 & 9 \\
MNA & 6 & 5 & 0 & 1 \\
SAS & 5 & 4 & 1 & 0 \\
SSA & 26 & 13 & 5 & 8 \\
Total & $\mathbf{8 7}$ & $\mathbf{4 2}$ & $\mathbf{2 5}$ & $\mathbf{2 0}$ \\
\hline
\end{tabular}

Note: For region identifiers see Table 1. 
Table 3: Urban and rural poverty measures using a poverty line of \$1.08/day (in 1993 PPP)

\begin{tabular}{|c|c|c|c|c|c|c|c|c|}
\hline & Number & f poor in 1 & hillions & \multicolumn{3}{|c|}{ Headcount index $(\%)$} & $\begin{array}{c}\text { Urban } \\
\text { share of } \\
\text { the poor } \\
(\%)\end{array}$ & $\begin{array}{c}\text { Urban } \\
\text { share of } \\
\text { population } \\
(\%)\end{array}$ \\
\hline 1993 & & & & & & & & \\
\hline EAP & 28.71 & 407.17 & 435.88 & 5.55 & 35.47 & 26.17 & 6.59 & 31.09 \\
\hline China & 10.98 & 331.38 & 342.36 & 3.33 & 39.05 & 29.05 & 3.21 & 29.77 \\
\hline ECA & 6.12 & 6.37 & 12.49 & 2.06 & 3.66 & 2.65 & 48.98 & 63.06 \\
\hline LAC & 26.07 & 28.55 & 54.62 & 7.82 & 22.38 & 11.85 & 47.73 & 72.33 \\
\hline MNA & 0.77 & 4.29 & 5.07 & 0.61 & 3.76 & 2.09 & 15.29 & 52.82 \\
\hline SAS & 107.48 & 383.30 & 490.78 & 35.30 & 43.55 & 41.43 & 21.90 & 25.70 \\
\hline India & 94.28 & 324.55 & 418.83 & 40.06 & 48.88 & 46.57 & 22.51 & 26.17 \\
\hline SSA & 66.42 & 206.73 & 273.15 & 40.21 & 53.07 & 49.24 & 24.32 & 29.78 \\
\hline Total & 235.58 & 1036.41 & 1271.99 & 13.50 & 36.58 & 27.78 & 18.52 & 38.12 \\
\hline Less China & 224.60 & 705.03 & 929.63 & 15.86 & 35.53 & 27.34 & 24.16 & 41.64 \\
\hline \multicolumn{9}{|l|}{1996} \\
\hline EAP & 19.34 & 264.54 & 283.88 & 3.34 & 23.00 & 16.41 & 6.81 & 33.49 \\
\hline China & 6.59 & 204.60 & 211.20 & 1.68 & 24.80 & 17.35 & 3.12 & 32.24 \\
\hline ECA & 7.77 & 9.15 & 16.93 & 2.60 & 5.26 & 3.58 & 45.93 & 63.19 \\
\hline LAC & 31.34 & 28.95 & 60.29 & 8.79 & 22.67 & 12.44 & 51.98 & 73.64 \\
\hline MNA & 0.75 & 5.05 & 5.80 & 0.53 & 4.23 & 2.24 & 12.88 & 53.92 \\
\hline SAS & 115.43 & 384.97 & 500.40 & 34.82 & 41.63 & 39.84 & 23.07 & 26.39 \\
\hline India & 103.06 & 324.75 & 427.81 & 40.52 & 46.77 & 45.09 & 24.09 & 26.81 \\
\hline SSA & 82.32 & 221.37 & 303.69 & 43.41 & 53.97 & 50.63 & 27.11 & 31.62 \\
\hline Total & 256.96 & 914.02 & 1170.98 & 13.56 & 31.45 & 24.39 & 21.94 & 39.47 \\
\hline Less China & 250.36 & 709.42 & 959.78 & 16.66 & 42.02 & 26.78 & 26.09 & 41.93 \\
\hline \multicolumn{9}{|l|}{1999} \\
\hline EAP & 19.53 & 268.24 & 287.76 & 3.02 & 23.46 & 16.08 & 6.79 & 36.10 \\
\hline China & 6.93 & 220.78 & 227.71 & 1.59 & 27.00 & 18.16 & 3.04 & 34.89 \\
\hline ECA & 7.42 & 10.65 & 18.07 & 2.48 & 6.11 & 3.81 & 41.08 & 63.23 \\
\hline LAC & 33.90 & 29.85 & 63.75 & 8.91 & 23.50 & 12.57 & 53.18 & 74.97 \\
\hline MNA & 1.31 & 5.17 & 6.47 & 0.87 & 4.19 & 2.37 & 20.18 & 54.83 \\
\hline SAS & 120.15 & 402.40 & 522.55 & 33.41 & 41.59 & 39.37 & 22.99 & 27.10 \\
\hline India & 102.51 & 321.06 & 423.58 & 37.38 & 44.30 & 42.40 & 24.20 & 27.45 \\
\hline SSA & 92.05 & 228.85 & 320.90 & 42.57 & 53.14 & 49.61 & 28.69 & 33.43 \\
\hline Total & 274.36 & 945.15 & 1219.51 & 13.37 & 31.87 & 24.31 & 22.50 & 40.89 \\
\hline Less China & 267.42 & 724.38 & 991.80 & 16.56 & 33.72 & 26.35 & 26.96 & 42.92 \\
\hline \multicolumn{9}{|l|}{2002} \\
\hline EAP & 16.27 & 223.23 & 239.50 & 2.28 & 19.83 & 13.03 & 6.79 & 38.79 \\
\hline China & 4.00 & 175.01 & 179.01 & 0.80 & 22.44 & 13.98 & 2.24 & 37.68 \\
\hline ECA & 2.48 & 4.94 & 7.42 & 0.83 & 2.87 & 1.57 & 33.40 & 63.45 \\
\hline LAC & 38.33 & 26.60 & 64.93 & 9.49 & 21.15 & 12.26 & 59.03 & 76.24 \\
\hline MNA & 1.21 & 4.88 & 6.09 & 0.75 & 3.82 & 2.11 & 19.87 & 55.75 \\
\hline SAS & 125.40 & 394.34 & 519.74 & 32.21 & 39.05 & 37.15 & 24.13 & 27.83 \\
\hline India & 106.64 & 316.42 & 423.06 & 36.20 & 41.96 & 40.34 & 25.21 & 28.09 \\
\hline SSA & 98.84 & 228.77 & 327.61 & 40.38 & 50.86 & 47.17 & 30.17 & 35.24 \\
\hline Total & 282.52 & 882.77 & 1165.29 & 12.78 & 29.32 & 22.31 & 24.24 & 42.34 \\
\hline Less China & 278.52 & 707.76 & 986.28 & 16.28 & 31.72 & 25.02 & 28.24 & 43.40 \\
\hline
\end{tabular}

Note: For region identifiers see Table 1. 
Table 4: Urban and rural poverty measures using a poverty line of \$2.15/day (in 1993 PPP)

\begin{tabular}{|c|c|c|c|c|c|c|c|}
\hline & \multicolumn{3}{|c|}{ Number of poor in millions } & \multicolumn{3}{|c|}{ Headcount index (\%) } & \multirow{2}{*}{$\begin{array}{c}\text { Urban share } \\
\text { of the poor } \\
(\%)\end{array}$} \\
\hline & Urban & Rural & Total & Urban & Rural & Total & \\
\hline \multicolumn{8}{|l|}{1993} \\
\hline EAP & 199.84 & 976.38 & 1176.22 & 38.60 & 85.07 & 70.62 & 16.99 \\
\hline China & 117.33 & 752.19 & 869.52 & 35.57 & 88.64 & 73.79 & 13.49 \\
\hline ECA & 43.60 & 34.49 & 78.09 & 14.68 & 19.83 & 16.58 & 55.83 \\
\hline LAC & 75.92 & 60.35 & 136.28 & 22.77 & 47.30 & 29.56 & 55.71 \\
\hline MNA & 15.96 & 40.82 & 56.78 & 12.49 & 35.75 & 23.46 & 28.11 \\
\hline SAS & 237.38 & 770.65 & 1008.02 & 77.97 & 87.56 & 85.09 & 23.55 \\
\hline India & 193.65 & 607.54 & 801.19 & 82.28 & 91.50 & 89.09 & 24.17 \\
\hline SSA & 110.45 & 331.96 & 442.41 & 66.86 & 85.22 & 79.75 & 24.97 \\
\hline Total & 683.15 & 2214.65 & 2897.80 & 39.14 & 78.17 & 63.29 & 23.57 \\
\hline Less China & 565.83 & 1462.46 & 2028.28 & 39.97 & 73.69 & 59.65 & 27.90 \\
\hline \multicolumn{8}{|l|}{1996} \\
\hline EAP & 169.18 & 812.09 & 981.26 & 29.21 & 70.60 & 56.73 & 17.24 \\
\hline China & 101.47 & 598.05 & 699.52 & 25.85 & 72.49 & 57.45 & 14.51 \\
\hline ECA & 49.77 & 39.81 & 89.59 & 16.67 & 22.90 & 18.96 & 55.56 \\
\hline LAC & 95.61 & 61.17 & 156.78 & 26.80 & 47.89 & 32.36 & 60.98 \\
\hline MNA & 17.57 & 44.78 & 62.34 & 12.58 & 37.53 & 24.08 & 28.18 \\
\hline SAS & 259.94 & 813.58 & 1073.52 & 78.42 & 87.99 & 85.46 & 24.21 \\
\hline India & 215.45 & 629.45 & 844.90 & 84.70 & 90.65 & 89.05 & 25.50 \\
\hline SSA & 131.64 & 346.62 & 478.25 & 69.42 & 84.51 & 79.74 & 27.52 \\
\hline Total & 723.70 & 2118.04 & 2841.74 & 38.19 & 72.88 & 59.19 & 25.47 \\
\hline Less China & 622.23 & 1519.99 & 2142.21 & 41.41 & 90.02 & 59.78 & 29.05 \\
\hline \multicolumn{8}{|l|}{1999} \\
\hline EAP & 166.03 & 796.67 & 962.69 & 25.70 & 69.68 & 53.81 & 17.25 \\
\hline China & 89.22 & 593.80 & 683.02 & 20.46 & 72.62 & 54.48 & 13.06 \\
\hline ECA & 50.07 & 44.46 & 94.53 & 16.72 & 25.53 & 19.96 & 52.97 \\
\hline LAC & 102.65 & 61.56 & 164.21 & 26.99 & 48.47 & 32.36 & 62.51 \\
\hline MNA & 20.73 & 48.81 & 69.54 & 13.85 & 39.57 & 25.47 & 29.81 \\
\hline SAS & 270.88 & 846.45 & 1117.33 & 75.32 & 87.48 & 84.19 & 24.24 \\
\hline India & 218.06 & 649.41 & 867.47 & 79.52 & 89.60 & 86.83 & 25.14 \\
\hline SSA & 150.54 & 362.76 & 513.30 & 69.63 & 84.24 & 79.36 & 29.33 \\
\hline Total & 760.90 & 2160.71 & 2921.61 & 37.09 & 72.85 & 58.23 & 26.04 \\
\hline Less China & 671.68 & 1566.91 & 2238.60 & 41.58 & 72.94 & 59.48 & 30.00 \\
\hline \multicolumn{8}{|l|}{2002} \\
\hline EAP & 126.71 & 711.45 & 838.16 & 17.77 & 63.21 & 45.59 & 15.12 \\
\hline China & 53.45 & 507.48 & 560.93 & 10.68 & 65.07 & 43.81 & 9.53 \\
\hline ECA & 32.07 & 32.22 & 64.29 & 10.71 & 18.69 & 13.63 & 49.88 \\
\hline LAC & 109.25 & 58.36 & 167.61 & 27.06 & 46.39 & 31.65 & 65.18 \\
\hline MNA & 19.90 & 48.12 & 68.02 & 12.36 & 37.64 & 23.54 & 29.25 \\
\hline SAS & 290.29 & 876.30 & 1166.59 & 74.56 & 86.78 & 83.38 & 24.88 \\
\hline India & 229.91 & 667.89 & 897.80 & 78.05 & 88.57 & 85.62 & 25.61 \\
\hline SSA & 167.72 & 370.83 & 538.55 & 68.52 & 82.45 & 77.54 & 31.14 \\
\hline Total & 745.94 & 2097.29 & 2843.23 & 33.73 & 69.65 & 54.44 & 26.24 \\
\hline Less China & 692.48 & 1589.81 & 2282.30 & 40.48 & 71.25 & 57.89 & 30.34 \\
\hline
\end{tabular}

Note: For region identifiers see Table 1. 
Table 5: Decomposition of the change in poverty 1993-2002

\begin{tabular}{|c|c|c|c|c|}
\hline & $\begin{array}{c}\text { Total change in } \\
\text { headcount index } \\
1993-2002 \\
\text { (\% points) }\end{array}$ & Rural sector & Decomposition & $\begin{array}{c}\text { Population } \\
\text { shift }\end{array}$ \\
\hline \multicolumn{5}{|l|}{$\$ 1.08 /$ day } \\
\hline EAP & -13.14 & -9.57 & -1.27 & -2.31 \\
\hline China & -15.07 & -11.04 & -1.02 & -3.01 \\
\hline ECA & -1.08 & -0.29 & -0.78 & -0.01 \\
\hline LAC & 0.41 & -0.29 & 1.27 & -0.57 \\
\hline MNA & 0.01 & 0.03 & 0.08 & -0.09 \\
\hline SAS & -4.28 & -3.28 & -0.87 & -0.14 \\
\hline India & -6.23 & -5.01 & -1.09 & -0.12 \\
\hline SSA & -2.07 & -1.43 & 0.06 & -0.70 \\
\hline Total & -5.47 & -4.20 & -0.31 & -0.96 \\
\hline \multicolumn{5}{|l|}{$\$ 2.15 /$ day } \\
\hline EAP & -25.03 & -13.37 & -8.08 & -3.58 \\
\hline China & -29.98 & -15.58 & -9.95 & -4.45 \\
\hline ECA & -2.96 & -0.42 & -2.52 & -0.02 \\
\hline LAC & 2.09 & -0.22 & 3.27 & -0.96 \\
\hline MNA & 0.08 & 0.84 & -0.08 & -0.68 \\
\hline SAS & -1.72 & -0.57 & -0.96 & -0.18 \\
\hline India & -3.47 & -2.12 & -1.20 & -0.15 \\
\hline SSA & -2.21 & -1.79 & 0.58 & -1.00 \\
\hline Total & -8.85 & -4.92 & -2.29 & -1.64 \\
\hline
\end{tabular}

Note: For region identifiers see Table 1.

Table 6: Regression coefficients of poverty measures on urban population shares

\begin{tabular}{|c|c|c|c|c|c|c|}
\hline & \multicolumn{3}{|c|}{$\$ 1$ a day poverty line } & \multicolumn{3}{|c|}{$\$ 2$ a day poverty line } \\
\hline & Urban & Rural & National & Urban & Rural & National \\
\hline $\begin{array}{l}\text { Regions } \\
\text { by year } \\
(\mathrm{n}=24)\end{array}$ & $\begin{array}{c}-0.206 \\
(0.161 ; 0.218)\end{array}$ & $\begin{array}{c}-1.107 \\
(0.462 ; 0.028)\end{array}$ & $\begin{array}{c}-0.934 \\
(0.386 ; 0.027)\end{array}$ & $\begin{array}{c}-1.170 \\
(0.696 ; 0.111)\end{array}$ & $\begin{array}{c}-1.397 \\
(0.636 ; 0.042)\end{array}$ & $\begin{array}{c}-1.592 \\
(0.727 ; 0.043)\end{array}$ \\
\hline $\begin{array}{l}\text { Countries } \\
\text { by year } \\
(n=348)\end{array}$ & $\begin{array}{c}-0.422 \\
(0.172 ; 0.015)\end{array}$ & $\begin{array}{c}-0.708 \\
(0.216 ; 0.001)\end{array}$ & $\begin{array}{c}-0.731 \\
(0.195 ; 0.000)\end{array}$ & $\begin{array}{c}-0.582 \\
(0.216 ; 0.008)\end{array}$ & $\begin{array}{c}-0.813 \\
(0.207 ; 0.000)\end{array}$ & $\begin{array}{c}-0.897 \\
(0.209 ; 0.000)\end{array}$ \\
\hline
\end{tabular}

Note: Both poverty measures and urban population share in \%. The first number in parentheses is the White standard error, the second number is the prob. value; all regressions included regional or country fixed effects. 
Table 7: Estimated elasticities of $H^{u} / H$ to $S^{u}$ by region

\begin{tabular}{lll}
\hline Region & $\$ 1$ a day & $\$ 2$ a day \\
\hline EAP & 1.419 & 0.270 \\
& $(0.489 ; 0.007 ; 32)$ & $(0.104 ; 0.015 ; 32)$ \\
& 0.170 & 0.261 \\
ECA & $(0.441 ; 0.701 ; 84)$ & $(0.228 ; 0.257 ; 84)$ \\
& 1.094 & 0.462 \\
LAC & $(0.481 ; 0.026 ; 84)$ & $(0.124 ; 0.000 ; 84)$ \\
& -0.443 & -0.038 \\
MNA & $(0.114 ; 0.001 ; 24)$ & $(0.152 ; 0.803 ; 24)$ \\
& 0.484 & 0.457 \\
SAS & $(0.130 ; 0.002 ; 20)$ & $(0.078 ; 0.000 ; 20)$ \\
& 0.184 & 0.154 \\
SSA & $(0.075 ; 0.016 ; 104)$ & $(0.045 ; 0.001 ; 104)$ \\
& & $\mathbf{0 . 1 2 7}$ \\
Total & $\mathbf{0 . 3 0 4}$ & $(0.023 ; 0.000 ; 348)$ \\
With regional & $\mathbf{0 . 3 9 8}$ & $(0.100 ; 0.000 ; 348)$ \\
fixed effects & $(0.040 ; 0.000 ; 348)$ \\
\hline
\end{tabular}

Note: The first number in parentheses is the White standard error, the second number is the prob. value and the third is the number of observations. The last row gives the regression for the total sample including a complete set of regional fixed effects. For region identifiers see Table 1. 
Table 8: Poverty gap indices for urban and rural areas

\begin{tabular}{|c|c|c|c|c|c|c|c|c|}
\hline & \multicolumn{4}{|c|}{$\$ 1.08 /$ day poverty line } & \multicolumn{4}{|c|}{$\$ 2.15 /$ day poverty line } \\
\hline & \multicolumn{3}{|c|}{ Poverty gap index (\%) } & \multirow{2}{*}{$\begin{array}{l}\text { Urban } \\
\text { share of } \\
\text { PG }(\%)\end{array}$} & \multicolumn{3}{|c|}{ Poverty gap index (\%) } & \multirow{2}{*}{$\begin{array}{l}\text { Urban } \\
\text { share of } \\
\text { PG (\%) }\end{array}$} \\
\hline & Urban & Rural & Total & & Urban & Rural & Total & \\
\hline \multicolumn{9}{|l|}{1993} \\
\hline EAP & 1.16 & 9.03 & 6.58 & 5.48 & 11.03 & 37.52 & 29.28 & 11.70 \\
\hline China & 0.67 & 10.1 & 7.46 & 2.50 & 9.15 & 40.22 & 31.52 & 8.12 \\
\hline ECA & 0.50 & 0.92 & 0.66 & 48.30 & 4.05 & 5.94 & 4.75 & 53.79 \\
\hline LAC & 2.65 & 9.48 & 4.54 & 42.21 & 8.95 & 22.38 & 12.67 & 51.12 \\
\hline MNA & 0.14 & 0.36 & 0.24 & 29.47 & 2.76 & 7.62 & 5.05 & 28.81 \\
\hline SAS & 9.65 & 11.60 & 11.10 & 22.36 & 35.04 & 41.34 & 39.72 & 22.67 \\
\hline India & 11.09 & 12.83 & 12.37 & 23.46 & 38.30 & 44.71 & 43.03 & 23.29 \\
\hline SSA & 20.17 & 22.14 & 21.55 & 27.87 & 35.93 & 47.34 & 43.94 & 24.35 \\
\hline Total & 4.54 & 10.80 & 8.41 & 20.56 & 15.38 & 36.23 & 28.28 & 20.73 \\
\hline Less China & 5.44 & 11.10 & 8.75 & 25.90 & 16.83 & 34.53 & 27.16 & 25.81 \\
\hline \multicolumn{9}{|l|}{1996} \\
\hline EAP & 0.69 & 5.14 & 3.65 & 6.36 & 7.73 & 27.22 & 20.69 & 12.51 \\
\hline China & 0.32 & 5.44 & 3.79 & 2.75 & 6.03 & 28.45 & 21.22 & 9.16 \\
\hline $\mathrm{ECA}$ & 0.62 & 1.40 & 0.91 & 43.34 & 4.81 & 7.44 & 5.78 & 52.60 \\
\hline LAC & 2.67 & 9.46 & 4.46 & 44.10 & 10.49 & 22.61 & 13.69 & 56.45 \\
\hline MNA & 0.10 & 0.84 & 0.44 & 12.16 & 2.65 & 10.08 & 6.08 & 23.53 \\
\hline SAS & 9.36 & 11.25 & 10.75 & 22.97 & 34.79 & 42.61 & 40.54 & 22.64 \\
\hline India & 11.22 & 13.09 & 12.59 & 23.89 & 39.07 & 46.24 & 44.32 & 23.63 \\
\hline SSA & 20.28 & 24.02 & 22.84 & 28.08 & 39.29 & 48.16 & 45.35 & 27.39 \\
\hline Total & 4.49 & 9.54 & 7.54 & 23.47 & 15.31 & 32.98 & 26.00 & 23.23 \\
\hline Less China & 5.57 & 11.16 & 8.82 & 26.50 & 17.73 & 34.78 & 27.63 & 26.91 \\
\hline \multicolumn{9}{|l|}{1999} \\
\hline EAP & 0.68 & 5.51 & 3.77 & 6.48 & 6.86 & 27.20 & 19.86 & 12.48 \\
\hline China & 0.35 & 6.34 & 4.25 & 2.87 & 4.87 & 29.51 & 20.94 & 8.08 \\
\hline ECA & 0.56 & 1.95 & 1.07 & 33.14 & 4.73 & 8.56 & 6.14 & 48.74 \\
\hline LAC & 2.66 & 9.79 & 4.45 & 44.91 & 10.32 & 23.40 & 13.59 & 56.91 \\
\hline MNA & 0.17 & 0.77 & 0.44 & 20.61 & 3.18 & 10.78 & 6.61 & 26.33 \\
\hline SAS & 9.09 & 10.48 & 10.10 & 24.39 & 33.41 & 40.40 & 38.50 & 23.51 \\
\hline India & 10.36 & 10.95 & 10.78 & 26.36 & 36.33 & 42.11 & 40.52 & 24.61 \\
\hline SSA & 19.20 & 23.63 & 22.15 & 28.98 & 38.57 & 47.56 & 44.56 & 28.93 \\
\hline Total & 4.42 & 9.54 & 7.45 & 24.26 & 14.92 & 32.52 & 25.32 & 24.09 \\
\hline Less China & 5.52 & 10.76 & 8.51 & 27.83 & 17.63 & 33.67 & 26.79 & 28.25 \\
\hline \multicolumn{9}{|l|}{2002} \\
\hline EAP & 0.54 & 4.42 & 2.92 & 7.16 & 4.74 & 23.79 & 16.41 & 11.21 \\
\hline China & 0.238 & 4.96 & 3.11 & 2.99 & 2.331 & 25.341 & 16.35 & 5.57 \\
\hline ECA & 0.21 & 0.67 & 0.38 & 34.82 & 2.55 & 5.38 & 3.58 & 45.13 \\
\hline LAC & 3.01 & 8.60 & 4.33 & 52.86 & 10.46 & 21.44 & 13.07 & 61.03 \\
\hline MNA & 0.15 & 0.74 & 0.41 & 19.98 & 2.79 & 10.06 & 6.01 & 25.92 \\
\hline SAS & 8.67 & 9.18 & 9.04 & 26.71 & 32.66 & 39.02 & 37.25 & 24.40 \\
\hline India & 10.04 & 10.03 & 10.03 & 28.10 & 35.38 & 40.77 & 39.26 & 25.32 \\
\hline SSA & 16.67 & 22.53 & 20.46 & 28.70 & 36.56 & 45.84 & 42.57 & 30.27 \\
\hline Total & 4.13 & 8.53 & 6.67 & 26.25 & 13.79 & 30.46 & 23.40 & 24.95 \\
\hline Less China & 5.27 & 9.77 & 7.82 & 29.26 & 17.14 & 32.24 & 25.69 & 28.95 \\
\hline
\end{tabular}


Table 9: Test for distributional effects of urbanization on poverty

\begin{tabular}{llllllll}
\hline & $\ln \mu$ & $(\ln \mu)^{2}$ & $S^{u}$ & $S^{u 2}$ & $S^{u} \ln \mu$ & $\mathrm{R}^{2}$ & $\begin{array}{l}\text { Prob. } \\
\text { for test }\end{array}$ \\
\hline$\$ 1$ & 3.912 & -0.840 & -9.073 & -0.043 & 2.659 & 0.574 & 0.085 \\
& $(1.303 ; 0.003)$ & $(0.162 ; 0.000)$ & $(4.678 ; 0.054)$ & $(4.217 ; 0.992)$ & $(1.090 ; 0.015)$ & & \\
$\$ 2$ & 4.266 & -0.732 & -4.086 & -1.590 & 1.733 & 0.607 & 0.160 \\
& $(0.855 ; 0.000)$ & $(0.107 ; 0.000)$ & $(3.134 ; 0.194)$ & $(2.810 ; 0.572)$ & $(0.726 ; 0.018)$ & & \\
\hline
\end{tabular}

Note: Prob. value based on robust standard errors in parentheses. All regressions included a constant term. $\mathrm{N}=348$. 


\section{Appendix 1: Theoretical exposition}

To outline our approach in more precise terms, let $Z^{r}$ denote the international rural poverty line, which is fixed across all countries on the basis of existing PPP exchange rates; for example, this might be “\$1 a day" in international PPP \$”. Our international urban poverty line at a given date is $\left(Z_{i}^{u} / Z_{i}^{r}\right) Z^{r}$ where $Z_{i}^{k}$ is the national poverty line for sector $k=u, r$ in country $i$, based on the PA. The aggregate international headcount indices of rural and urban poverty across $N$ countries indexed $i=1, . ., N$ are then:

$$
H^{r}=\sum_{i=1}^{N} S_{i}^{r} F_{i}^{r}\left(Z^{r}\right) \text { and } H^{u}=\sum_{i=1}^{N} S_{i}^{u} F_{i}^{u}\left[\left(Z_{i}^{u} / Z_{i}^{r}\right) Z^{r}\right]
$$

where $S_{i}^{k}$ is country $i$ 's share of the total population in sector $k$ and $F_{i}^{k}$ is the cumulative distribution of consumption in sector $k$ of country $i\left(F_{i}^{k}\right.$ is a non-decreasing function for all $k$ and $i$ ). The "global" aggregate headcount index is then $H=S^{r} H^{r}+S^{u} H^{u}$. The urban share of the poor in country $i$ is $P_{i}^{u} \equiv S_{i}^{u} H_{i}^{u} / H_{i}$ while it is $P^{u} \equiv S^{u} H^{u} / H$ globally.

How will our change in methodology affect existing poverty measures? Consider first the international ("\$1 a day") measures. For these, our change will obviously increase the overall headcount index as long as $Z_{i}^{u} \geq Z_{i}^{r}$ for all $i$. The change will also increase $P_{i}^{u}$ for all $i$. The outcome is less obvious when the comparison is made with the national measures:

$$
H_{P A}^{r}=\sum_{i=1}^{N} S_{i}^{r} F_{i}^{r}\left(Z_{i}^{r}\right) \text { and } H_{P A}^{u}=\sum_{i=1}^{N} S_{i}^{u} F_{i}^{u}\left(Z_{i}^{u}\right)
$$

(Here we use the subscript "PA" to signify the urban and rural poverty measures based on the national poverty lines used in the country-specific PA's.) There is nothing very general one can say about the effect of switching from the national poverty lines to the international lines as this will clearly depend on the level of the international line as well as the properties of the distribution functions, $F_{i}{ }^{k}$. However some special cases are instructive. Suppose that the international rural line is set at the lower bound of the national poverty lines. Clearly then both 
the urban and rural international poverty measures (based on (A1)) will be no higher than those based on the aggregation of national measures (based on (A2). (This reverses when the international line is set at the upper bound of the national lines.) This case is of interest given that (as noted above) the " $\$ 1$ a day" line is deliberately conservative, in that it is intended to be a poverty line appropriate to the poorest countries (Ravallion et al., 1991; World Bank, 1990). The implication for the share of total poverty found in rural areas is theoretically ambiguous.

Note, however, that the $\$ 1$ a day line is not strictly a lower bound, but rather an average of the lines found amongst low-income countries. The precise line used by the Bank is the median of the lowest 10 poverty lines in the original compilation of (largely rural) poverty lines, as documented in Ravallion et al., (1991) (although the PPPs have been updated and revised since then; see Chen and Ravallion, 2004, for details). The fact that the line is not a strict lower bound means that the curvature properties of the distribution functions start to come into play. For example, if the international poverty line is set at the mean of the national lines and these are everywhere below the mode of the (unimodal) distributions then the measures based on the international lines will again be below those based on the aggregation of national poverty measures. (This follows from well-known properties of convex functions.) However, putting these special cases to one side, the implications of re-calculating the urban-rural poverty profile for the developing world based on international poverty lines rather than national poverty lines are theoretically ambiguous. 
Appendix 2: Survey data sets by country, date and welfare indicator

\begin{tabular}{|c|c|c|c|c|c|}
\hline Region & Country & $\begin{array}{l}\text { Share of } 2002 \\
\text { population } \\
\text { represented (\%) }\end{array}$ & Survey years & $\begin{array}{l}\text { Welfare } \\
\text { measure }\end{array}$ & $\begin{array}{l}\text { Ratio of urban/ } \\
\text { rural poverty lines } \\
\text { (1993) }\end{array}$ \\
\hline \multicolumn{2}{|c|}{ East Asia and Pacific } & \multirow[t]{9}{*}{94.61} & & & 1.30 \\
\hline & Cambodia & & 1994, 2004, & Expenditure & 1.23 \\
\hline & China & & 1993, 1999, 2002 & Expenditure & 1.37 \\
\hline & Indonesia & & 1993, 1999, 2002 & Expenditure & 1.11 \\
\hline & Laos & & 1992 & Expenditure & 1.04 \\
\hline & Mongolia & & 2002 & Expenditure & 1.16 \\
\hline & Philippines & & 1998,2000 & Expenditure & 1.46 \\
\hline & Thailand & & 2002 & Expenditure & 1.54 \\
\hline & Vietnam & & 1992/93, 1998, 2002 & Expenditure & 1.24 \\
\hline \multicolumn{2}{|c|}{ Europe and Central Asia } & \multirow[t]{22}{*}{91.82} & & & 1.05 \\
\hline & Albania & & $\begin{array}{l}1996,2002 \\
1998 / 99,2001,2002,\end{array}$ & Expenditure & 1.05 \\
\hline & Armenia & & 2003 & Expenditure & 1.02 \\
\hline & Azerbaijan & & $2001,2002,2003$ & Expenditure & 1.01 \\
\hline & Belarus & & 1998, 2001, 2002 & Expenditure & 1.00 \\
\hline & Bulgaria & & 1995, 2001, 2003 & Expenditure & 1.04 \\
\hline & Estonia & & 2000,2002 & Expenditure & 0.98 \\
\hline & Georgia & & 1997, 1999, 2002 & Expenditure & 1.02 \\
\hline & Hungary & & 1999,2002 & Expenditure & 0.99 \\
\hline & Kazakhstan & & 1996,2002 & Expenditure & 1.04 \\
\hline & Kyrgyz & & $1998,2000,2002$ & Expenditure & 1.10 \\
\hline & Latvia & & 2002 & Expenditure & 1.02 \\
\hline & Lithuania & & 1998,2002 & Expenditure & 1.01 \\
\hline & Macedonia & & 1999,2002 & Expenditure & 1.05 \\
\hline & Moldova & & $1997,1998,2002$ & Expenditure & 1.06 \\
\hline & Poland & & 1999,2002 & Expenditure & 1.04 \\
\hline & Romania & & 1998,2002 & Expenditure & 1.17 \\
\hline & Russia & & 1998,2002 & Expenditure & 1.07 \\
\hline & Tajikhstan & & 1999,2002 & Expenditure & 1.06 \\
\hline & Turkey & & 2002 & Expenditure & 1.03 \\
\hline & Ukraine & & 1996,2003 & Expenditure & 1.04 \\
\hline & Uzbekistan & & 1998,2002 & Expenditure & 1.04 \\
\hline \multicolumn{6}{|c|}{ Latin America and the } \\
\hline \multirow[t]{10}{*}{ Caribbea } & & \multirow[t]{10}{*}{96.67} & & & 1.44 \\
\hline & Argentina & & $\begin{array}{l}1992,1996,1998,2002 \\
2003,2004\end{array}$ & Income & 1.43 \\
\hline & Bolivia & & 1997, 1999, 2002 & Income & 1.40 \\
\hline & Brazil & & $\begin{array}{l}1990,1993,1996,1998 \\
2001,2002,2003,2004 \\
1990,1994,1996,1998\end{array}$ & Income & 1.55 \\
\hline & Chile & & 2000,2003 & Income & 1.43 \\
\hline & Colombia & & 1996, 1998, 2000, 2003 & Income & 1.25 \\
\hline & Costa Rica & & 1992, 1998, 2001, 2004 & Income & 1.36 \\
\hline & Dominican Rep & & $1992,2000,2003$ & Expenditure & 1.06 \\
\hline & Ecuador & & 1994,1998 & Income & 1.24 \\
\hline & El Salvador & & $1995,1998,2000,2002$ & Income & 1.71 \\
\hline
\end{tabular}




\begin{tabular}{|c|c|c|c|c|}
\hline Guatemala & & $1998,2000,2002$ & Income & 1.09 \\
\hline Haiti & & 2001 & Income & 1.43 \\
\hline Honduras & & $1992,1999,2003$ & Income & 1.41 \\
\hline Jamaica & & $\begin{array}{l}1990,1996,2000 \\
1992,1994,1998,2000\end{array}$ & Expenditure & 0.90 \\
\hline Mexico & & 2002 & Expenditure & 1.44 \\
\hline Nicaragua & & 1993, 1998, 2001 & Income & 1.43 \\
\hline Panama & & 1996, 2002, & Income & 1.43 \\
\hline Paraguay & & 1998,2003 & Income & 1.43 \\
\hline $\begin{array}{l}\text { Peru } \\
\text { Trinidad \& }\end{array}$ & & 1994,2002 & Income & 1.26 \\
\hline Tobago & & 1992 & Income & 1.43 \\
\hline Uruguay & & 1992, 1998, 2001, 2003 & Income & 1.43 \\
\hline Venezuela & & 1992, 1996, 2004 & Income & 1.43 \\
\hline Middle East and North & & & & \\
\hline Africa & 69.56 & & & 1.10 \\
\hline Egypt & & $1995,1999 / 00$ & Expenditure & 1.09 \\
\hline Iran & & 1994, 1999, & Expenditure & 1.13 \\
\hline Jordan & & $2002 / 03$ & Expenditure & 1.13 \\
\hline Morocca & & 1990/91, 1998/99 & Expenditure & 1.29 \\
\hline Tunisia & & 1995,2000 & Expenditure & 1.18 \\
\hline Yemen & & 1998 & Expenditure & 0.99 \\
\hline South Asia & 98.48 & & & 1.30 \\
\hline Bangladesh & & 1991/92, 1995/96, 2000 & Expenditure & 1.29 \\
\hline India & & 1993/94, 2005 & Expenditure & 1.37 \\
\hline Nepal & & $\begin{array}{l}1995 / 96,2003 / 04 \\
1992 / 93,1998 / 99\end{array}$ & Expenditure & 1.24 \\
\hline Pakistan & & $2001 / 02$ & Expenditure & 1.13 \\
\hline Sri Lanka & & 1999/00, 2002 & Expenditure & 1.10 \\
\hline Sub-Saharan Africa & 75.03 & & & 1.29 \\
\hline Benin & & 2003 & Expenditure & 1.79 \\
\hline Botswana & & 1993/94, & Expenditure & 1.45 \\
\hline Burkina Faso & & 1994, 1998, 2003 & Expenditure & 1.45 \\
\hline Burundi & & 1998 & Expenditure & 1.45 \\
\hline Cameroon & & 1996, 2001 & Expenditure & 1.45 \\
\hline Cape Verde & & 2001 & Expenditure & 1.45 \\
\hline Cote d'Ivoire & & 1998,2002 & Expenditure & 1.25 \\
\hline Ethiopia & & 2000 & Expenditure & 1.46 \\
\hline Gambia & & 1998 & Expenditure & 1.26 \\
\hline Ghana & & 1991/92, 1998/99, & Expenditure & 1.35 \\
\hline Kenya & & 1994, 1997 & Expenditure & 1.45 \\
\hline Lesotho & & 1995 & Expenditure & 1.45 \\
\hline Madagascar & & 1997,2001 & Expenditure & 1.14 \\
\hline Malawi & & $2004 / 05$ & Expenditure & 1.45 \\
\hline Mali & & 1994, 2001 & Expenditure & 1.45 \\
\hline Mauritania & & 1995/96, 2000 & Expenditure & 1.10 \\
\hline Mozambique & & 1996/97, 2002/03, & Expenditure & 1.67 \\
\hline Niger & & $1994 / 95$ & Expenditure & 1.50 \\
\hline Nigeria & & 1996/97, 2003 & Expenditure & 1.05 \\
\hline Rwanda & & 1997,2000 & Expenditure & 1.45 \\
\hline Senegal & & 1994/95, 2001 & Expenditure & 1.63 \\
\hline
\end{tabular}




\begin{tabular}{lllll}
\hline & South Africa & 1995,2000 & Expenditure & 1.45 \\
& Swaziland & $2000 / 01$, & Expenditure & 1.45 \\
& Tanzania & $1991 / 92,2000 / 01$ & Expenditure & 1.21 \\
& Uganda & $1992 / 93,1999,2002$ & Expenditure & 1.10 \\
& Zambia & $1996,1998,2002 / 03$ & Expenditure & 1.45 \\
Total & & & & 1.30 \\
\hline
\end{tabular}

Notes: The ratio of rural to urban poverty lines by region and total is a population weighted average. 